\title{
Antioxidant Enzyme Activities and Secondary Metabolite Profiling of Oil Palm Seedlings Treated with Combination of NPK Fertilizers Infected with Ganoderma boninense
}

\author{
Mahbod Sahebi $\mathbb{D}^{1}{ }^{1}$ Mohamed M. Hanafi $\left(\mathbb{D},{ }^{1,2,3}\right.$ Hasmah Mohidin, ${ }^{4,5,6}$ \\ M. Y. Rafii $\left(\mathbb{D},{ }^{1}\right.$ Parisa Azizi $\left(\mathbb{D},{ }^{2}\right.$ Abu Seman Idris, ${ }^{7}$ A. Fariz, ${ }^{2}$ Rambod Abiri, ${ }^{8}$ \\ Sima Taheri, ${ }^{9}$ and Mehdi Moradpoor ${ }^{2}$ \\ ${ }^{1}$ Laboratory of Climate-Smart Food Crop Production, Institute of Tropical Agriculture and Food Security, \\ Universiti Putra Malaysia, 43400 Serdang, Selangor, Malaysia \\ ${ }^{2}$ Laboratory of Plantation Science and Technology, Institute of Plantation Studies, Universiti Putra Malaysia, \\ 43400 Serdang, Selangor, Malaysia \\ ${ }^{3}$ Department of Land Management, Faculty of Agriculture, Universiti Putra Malaysia, 43400 Serdang, Selangor, Malaysia \\ ${ }^{4}$ Faculty of Agrotechnology and Plantation, Universiti Teknologi MARA, Sarawak Branch, 94300 Kota Samarahan, Malaysia \\ ${ }^{5}$ Natural Product Research Development Centre, Universiti Teknologi MARA, Sarawak Branch, 94300 Kota Samarahan, Malaysia \\ ${ }^{6}$ Faculty of Agrotechnology and Plantation, Universiti Teknologi MARA, 40450 Shah Alam, Selangor, Malaysia \\ ${ }^{7}$ Biological Research Division, GanoDROP Unit, Malaysia Palm Oil Board, No. 6, Persiaran Institusi, Bandar Baru Bangi, \\ 43000 Kajang, Selangor, Malaysia \\ ${ }^{8}$ Department of Biochemistry, Faculty of Biotechnology and Biomolecular Sciences, Universiti Putra Malaysia, \\ 43400 Serdang, Selangor, Malaysia \\ ${ }^{9}$ Department of Crop Science, Faculty of Agriculture, Universiti Putra Malaysia, 43400 Serdang, Selangor, Malaysia
}

Correspondence should be addressed to Mohamed M. Hanafi; mmhanafi@upm.edu.my

Received 6 October 2017; Revised 28 November 2017; Accepted 20 December 2017; Published 12 March 2018

Academic Editor: Antonio Teixeira

Copyright (C) 2018 Mahbod Sahebi et al. This is an open access article distributed under the Creative Commons Attribution License, which permits unrestricted use, distribution, and reproduction in any medium, provided the original work is properly cited.

Oil palm (Elaeis guineensis Jacq) is one of the major sources of edible oil. Reducing the effect of Ganoderma, main cause of basal stem rot (BSR) on oil palm, is the main propose of this study. Understanding the oil palm defense mechanism against Ganoderma infection through monitoring changes in the secondary metabolite compounds levels before/after infection by Ganoderma under different fertilizing treatment is required. Oil palm requires macro- and microelements for growth and yield. Manipulating the nutrient for oil palm is a method to control the disease. The 3-4-month-old oil palm seedlings were given different macronutrient treatments to evaluate induction of defense related enzymes and production of secondary metabolite compounds in response to G. boninense inoculation. The observed trend of changes in the infected and uninfected seedlings was a slightly higher activity for $\beta$-1,3-glucanases, chitinase, peroxidase, and phenylalanine ammonia-lyase during the process of pathogenesis. It was found that PR proteins gave positive response to the interaction between oil palm seedlings and Ganoderma infection. Although the responses were activated systematically, they were short-lasting as the changes in enzymes activities appeared before the occurrence of visible symptoms. Effect of different nutrients doses was obviously observed among the results of the secondary metabolite compounds. Many identified/unidentified metabolite compounds were presented, of which some were involved in plant cell defense mechanism against pathogens, mostly belonging to alkaloids with bitter-tasting nitrogenous-compounds, and some had the potential to be used as new markers to detect basal stem rot at the initial step of disease.

\section{Introduction}

Oil palm (Elaeis guineensis Jacq.) is one of the world's sources of edible oil produced largely in Indonesia and Malaysia.
Beside the palm oil and kernel oil, various products such as paper, pulp, particle boards, fertilizer, energy, and biofuels are derived from fiber, empty fruit bunches, and trunk of oil palm $[1,2]$. Annually, the increasing demands for the oil palm 
products lead to expanding the cultured area of this tree in the major producing countries $[3,4]$.

Basal stem rot (BSR) disease caused by Ganoderma boninense is a serious threat for oil palm [5]. Reportedly, between 30 and $70 \%$ of oil palm production is usually lost because of BSR during repeating planting cycles [6]. The Ganoderma spp. attack the roots of palm, then spread slowly to the stem's bole, and cause dry rot that stops nutrient uptake and transport [7]. This infection leads to decrease in the ability of fruits producing and in the sever levels causes collapse of the trunk. Fruiting bodies of Ganoderma on the oil palm are not detectable till more than half of the internal tissues would be rotted [5]. Currently, research on biochemical and molecular aspects of oil palm at the early stage of the BSR disease is ongoing to understand interactions between palm and Ganoderma. In this regard, any changes in defense-responsive genes, transcription factors, proteins, and metabolite compounds should be monitored between healthy and Ganoderma-inoculated oil palm seedlings.

Plants have to develop their chemical-defense metabolites to stand unfavorable conditions and survive. These chemicaldefense metabolites can be either resistance against pathogen or tolerance towards abiotic stress [8]. Therefore, induction of defense metabolite compounds in oil palm leaves may involve in tolerance of tree and acts as defense mechanism against Ganoderma [9]. Reportedly, the amount of secondary metabolite compounds in plants is affected by Phosphate (P) and Potassium (K) fertilizers [10-12]. It was proposed that production of cellulose, starch, and non-nitrogen containing secondary metabolite compounds and some of important bioactive compounds would be correlated and increased in well-fertilized crops [13]. Results of another study showed that application of combined biofertilizers, NPK fertilizer, and vermicompost obviously effected biochemical and morphophysiological responses of mustard plant. All these changes lead to synthesis and accretion of some secondary metabolite compounds; also some pigment contents, such as proline, sugar, and chlorophyll in plant leaves, resulted in regulating plant osmosis and growth improvement [14].

Effects of N, P, and $\mathrm{K}$ fertilizing on resistance of oil palm against Ganoderma via induction of fungi associated proteins need to be more considered. Comparison of metabolite compounds between NPK treated and untreated palms leaf extract is one of the methods to reveal the biochemical pathways induced by BSR disease. In the current research LC-MS as a metabolite profiling technique was applied to identify different metabolite compounds from leaves of two groups of NPK treated and untreated oil palm seedlings as another objective of this study. Profiling of these metabolite compounds will provide strong possibility to be used as biomarker discovery of BSR disease as well as understanding enhanced resistance of oil palm against Ganoderma [15].

\section{Material and Methods}

2.1. Site and Plant Material. The 3-4-month-old oil palm seedlings were obtained from the Federal Land Development Authority (FELDA) Agriculture Services Sdn Bhd, Sungai
TABLE 1: Fertilizer treatment levels for healthy and $(+G)$ seedlings inoculated with $G$. boninense.

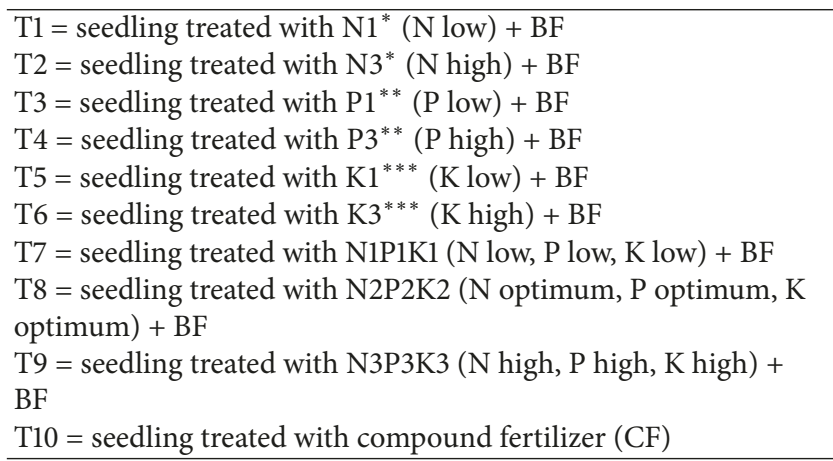

Note. ${ }^{*} \mathrm{P}$ and $\mathrm{K}$ optimum, ${ }^{* *} \mathrm{~N}$ and $\mathrm{K}$ optimum, ${ }^{* * *} \mathrm{~N}$ and $\mathrm{P}$ optimum. All treatments with $\mathrm{BF}=$ basic fertilizer $2 \% \mathrm{MgO}$ (source from kieserite) + micronutrients (TE). In the common commercial name (CF), where $\mathrm{N}$ stands for $\% \mathrm{~N}(12 \%), \mathrm{P} \%$ for $\mathrm{P}_{2} \mathrm{O}_{5}(12 \%), \mathrm{K}$ for $\% \mathrm{~K}_{2} \mathrm{O}(17 \%)$, and $\mathrm{Mg}$ for $\% \mathrm{MgO}$ $(2 \%)+\mathrm{TE}$.

Tekam, Jerantut, Pahang, Malaysia. Seedlings were given treatments as presented in Tables 1 and 2 to evaluate induction of defense related enzymes as a response to macronutrients application on $G$. boninense inoculated and healthy oil palm seedlings. The experiment was conducted at the experimental farm $\left(2^{\circ} 59^{\prime} 20.56^{\prime \prime} \mathrm{N}, 101^{\circ} 42^{\prime} 44.42^{\prime \prime} \mathrm{E}\right)$ under nursery shade house conditions. The experiment was designed as a splitplot with Ganoderma infected palms and uninfected palms as main plots and ten fertilizers treatment rates as subplots. Each main plot consisted of 500 healthy uninfected palms $(-\mathrm{G})$ as control and 500 Ganoderma $(+\mathrm{G})$ infected palms. The treatment comprised low, optimum, and high level for $\mathrm{N}, \mathrm{P}, \mathrm{K}$ nutrition with respective element in mixed fertilizers. The experiment was conducted using a randomized complete block design (RCBD), with five replications of ten seedlings per treatment. The nutrient levels of fertilizer were represented by N1, P1, and K1 for "low"; N2, P2, and K2 for "optimum"; and N3, P3, and K3 for "high" level. The recommended optimum level (referred to as N2, P2, and K2) applied to the oil palm seedlings was formulated based on the best vegetative growth performance obtained from the previous experiment. Fertilizer treatment was applied once every four weeks and the other elements, such as magnesium and micronutrients serve as basic fertilizer (BF). The composition of different fertilizer treatments used is presented in Table 1.

The sources of macronutrients were straight fertilizer consisting of urea $\left[\mathrm{CO}\left(\mathrm{NH}_{2}\right)_{2}\right]$ for $\mathrm{N}(46 \% \mathrm{~N})$, triple superphosphate $\left[\mathrm{Ca}\left(\mathrm{H}_{2} \mathrm{PO}_{4}\right)_{2} \mathrm{H}_{2} \mathrm{O}\right]$ for $\mathrm{P}\left(46 \% \mathrm{P}_{2} \mathrm{O}_{5}\right)$, and muriate of potash for $\mathrm{K}\left(60 \% \mathrm{~K}_{2} \mathrm{O}\right)$. The basic fertilizers $(\mathrm{BF})$ were referred to as the other elements and they include $\mathrm{MgO}$ (source from kieserite) and trace elements as recommended in commercial production pocket guide in nursery stage [16]. The control, T10, was the granular compound fertilizer (CF), commonly used commercial fertilizer, where $\mathrm{N}$ stands for $\%$ $\mathrm{N}(12 \%), \mathrm{P}$ for $\% \mathrm{P}_{2} \mathrm{O}_{5}(12 \%), \mathrm{K}$ for $\% \mathrm{~K}_{2} \mathrm{O}(17 \%)$, and $\mathrm{Mg}$ for $\% \operatorname{MgO}(2 \%)$.

2.2. Experimental Design and Treatment. Based on the pathological performances and occurrence of diseases incidence 
TABLE 2: Fertilizer and rates applied in the nursery trials.

\begin{tabular}{|c|c|c|c|c|c|c|c|c|c|}
\hline \multirow{2}{*}{ Month } & \multicolumn{3}{|c|}{ Urea } & \multicolumn{3}{|c|}{ TSP } & \multicolumn{3}{|c|}{ MOP } \\
\hline & $\mathrm{N} 1$ & N2 & N3 & P1 & $\mathrm{P} 2$ & P3 & $\mathrm{K} 1$ & $\mathrm{~K} 2$ & $\mathrm{~K} 3$ \\
\hline & \multicolumn{9}{|c|}{ g/palm } \\
\hline 4 & 0.69 & 0.99 & 1.29 & 0.693 & 0.99 & 1.29 & 1.15 & 1.64 & 2.13 \\
\hline 5 & 0.80 & 1.14 & 1.48 & 0.798 & 1.14 & 1.48 & 1.34 & 1.92 & 2.50 \\
\hline 6 & 0.88 & 1.26 & 1.64 & 0.882 & 1.26 & 1.64 & 1.57 & 2.24 & 2.91 \\
\hline 7 & 0.97 & 1.38 & 1.79 & 0.966 & 1.38 & 1.79 & 1.74 & 2.48 & 3.22 \\
\hline 8 & 1.03 & 1.47 & 1.91 & 1.029 & 1.47 & 1.91 & 1.90 & 2.72 & 3.54 \\
\hline 9 & 1.11 & 1.59 & 2.07 & 1.113 & 1.59 & 2.07 & 2.07 & 2.96 & 3.85 \\
\hline 10 & 1.20 & 1.71 & 2.22 & 1.197 & 1.71 & 2.22 & 2.24 & 3.20 & 4.16 \\
\hline 11 & 1.26 & 1.80 & 2.34 & 1.26 & 1.8 & 2.34 & 2.38 & 3.40 & 4.42 \\
\hline 12 & 1.34 & 1.92 & 2.50 & 1.344 & 1.92 & 2.50 & 2.49 & 3.56 & 4.63 \\
\hline 13 & 1.41 & 2.01 & 2.61 & 1.407 & 2.01 & 2.61 & 2.63 & 3.76 & 4.89 \\
\hline 14 & 1.47 & 2.10 & 2.73 & 1.47 & 2.1 & 2.73 & 2.74 & 3.92 & 5.10 \\
\hline Total & 12.16 & 17.37 & 22.58 & 12.16 & 17.37 & 22.58 & 22.26 & 31.80 & 41.34 \\
\hline
\end{tabular}

Note. Application of fertilizer in eleven months of experiment for growth analysis of oil palm seedlings. Amount of fertilizer needed for 1 replication for each level (g); TSP: triple superphosphate, MOP: muriate of potash. Level N1, P1, K1 (30\%) less than N2, P2, and K2. Level N3, P3, and K3 (30\%) more than N2, P2, and $\mathrm{K} 2$.

responses, treatments $\mathrm{T} 2, \mathrm{~T} 5, \mathrm{~T} 6, \mathrm{~T} 8$, and $\mathrm{T} 10$ were selected to be further evaluated of their enzymes activities. Treatments T2, T5, T6, T8, and T10 were arranged in a randomized complete block design with five replications of 20 seedlings per experimental unit with $G$. boninense infected and healthy palms for the detection test. Biochemical investigations were performed using three seedlings per treatment at weekly interval. Plants were destructively exercised at time course of being artificially inoculated by $G$. boninense and collected at week $1,4,8$, and 12 after inoculation (WAI) according to the treatment application and inoculation method.

2.3. Biochemical Analysis Assays. The random excised tips of primary root tissues were gently washed with distilled water, wrapped with aluminum foil, and maintained in liquid nitrogen. After reaching the laboratory, the root tissues were weighed, before being frozen, and stored at $-80^{\circ} \mathrm{C}$ for further analysis. The activity of four enzymes $\beta$-1,3-glucanase, chitinase, PAL, and POX was measured quantitatively using UV1700 Pharmaspec, UV-VIS Spectrophotometer, Shimadzu Corporation, Japan.

2.4. $\beta$-1,3-Glucanase Activity. The activity of $\beta$-1,3-glucanase was determined according to the Nelson Somogyi method $[17,18]$, with slight modifications. The $\beta$-1,3-glucanase was assayed by measuring the rate of reducing sugar production with laminarin (Sigma Aldrich) as the substrate. Glucose was used as the standard and the activity was expressed as $\mathrm{U} \mathrm{mL}^{-1}$ in unit $^{-1} \mathrm{~g}$ tissue.

2.5. Chitinase Activity. The activity of chitinase was determined according to Tonon et al. with slight modifications [19]. Chitinase activity was assayed by measuring the rate of $\mathrm{N}$-acetylglucosamine production using chitin (Sigma Aldrich) as the substrate. Chitinase activity was expressed as $\mathrm{U} \mathrm{mL}^{-1}$ with $\mathrm{N}$-acetylglucosamine as the standard.
2.6. Phenylalanine Ammonia-Lyase Activity. The activity of PAL was determined following the method of Chmielowska et al. with a slight modification [20]. The PAL activity was expressed in enzyme units (U) defined as $\mu \mathrm{mol}$ of transcinnamic acid formed per minute, per $\mathrm{mL}$ of solution.

2.7. Peroxidase Activity. Peroxidase (POX) activity was measured following the modifications applied to the protocol of Chmielowska et al. [20]. The blank consisted of reaction mixture without enzyme extract. The POX activity was expressed in enzyme units (U) defined as $\mu \mathrm{mol}$ of $\mathrm{DAB}$ oxidized per minute, per $\mathrm{mL}$ of solution.

2.8. Data Analysis. Data were compared by the analysis of variance (ANOVA) using SAS 9.3. When significant, means were compared by Duncan's Multiple Range Test (DMRT) at the 0.05 significance level. A $t$-test was performed for each treatment to compare infected and uninfected seedlings for plant biomass and for content in roots. All the assays were performed in triplicate using primary roots of noninoculated (healthy) and inoculated seedlings.

2.9. Metabolite Compounds Profiling. Based on the existence of diseases incidence responses, samples with the same treatments used for biochemical analysis were selected for this part of experiment. Aliquots of $500 \mathrm{mg}$ oil palm leaf powder were extracted with $1.5 \mathrm{ml}$ of $99.875 \%$ methanol acidified with formic acid $0.125 \%$. The extracts were solicited, centrifuged, and filtered through a $0.2 \mu \mathrm{m}$ polytetrafluoroethylene (PTFE) filter. For each accession, two biological replicates were prepared, resulting in total of 40 extracts. To check the technical variation, including extraction, sample analysis, and data processing, quality control data were prepared by pooling leaf material of several randomly chosen accessions, extracted using the same procedure and injected after every 10 accession sample extract. All extracts were analyzed using 
TABLE 3: Effect of N, P, and K nutrition and different enzyme activities of healthy and Ganoderma infected oil palm seedlings.

\begin{tabular}{|c|c|c|c|c|c|c|c|c|}
\hline $\begin{array}{l}\text { Week after } \\
\text { inoculation }\end{array}$ & $\begin{array}{c}\text { Ganoderma } \\
\text { infected } \\
\text { seedlings } \\
\left(\mathrm{UmL}^{-1}\right)\end{array}$ & $\begin{array}{l}\text { Control } \\
\left(\mathrm{Um} \mathrm{L}^{-1}\right)\end{array}$ & $t$ value & $\mathrm{T} 2$ & T5 & T6 & $\mathrm{T} 8$ & $\mathrm{~T} 10$ \\
\hline & \multicolumn{3}{|c|}{ Glucanase activity } & \multicolumn{4}{|c|}{$\begin{array}{c}\text { Effect of } \mathrm{N}, \mathrm{P}_{2} \mathrm{O}_{5} \text {, and } \mathrm{K}_{2} \mathrm{O} \text { nutrition on } \\
\text { glucanase activity }\end{array}$} & \\
\hline 1WAI & $10.097 \pm 0.96$ & $5.74 \pm 0.33$ & $10.43 \mathrm{~s}^{*}$ & $9.93^{\mathrm{a}}$ & $7.4^{\mathrm{b}}$ & $10.2^{\mathrm{a}}$ & $7.2^{\mathrm{b}}$ & $4.9^{c}$ \\
\hline 4WAI & $2.397 \pm 0.35$ & $2.5 \pm 0.47$ & $6.74 \mathrm{~s}^{*}$ & $3.3^{\mathrm{ab}}$ & $3.90^{\mathrm{a}}$ & $1.65^{\mathrm{c}}$ & $2.16^{\mathrm{bc}}$ & $1.25^{\mathrm{c}}$ \\
\hline 8WAI & $16.837 \pm 1.5$ & $10.44 \pm 1.15$ & $11.06 \mathrm{~s}^{*}$ & $17.78^{\mathrm{a}}$ & $9.75^{\mathrm{d}}$ & $16.2^{\mathrm{b}}$ & $14.56^{\mathrm{c}}$ & $9.9^{\mathrm{d}}$ \\
\hline \multirow[t]{2}{*}{$12 \mathrm{WAI}$} & $3.197 \pm 0.36$ & $4.188 \pm 0.69$ & $8.66 \mathrm{~s}^{*}$ & $3.48^{\mathrm{bc}}$ & $2.35^{\mathrm{c}}$ & $3.9^{\mathrm{b}}$ & $2.9^{\mathrm{bc}}$ & $5.87^{\mathrm{a}}$ \\
\hline & \multicolumn{3}{|c|}{ Chitinase activity } & \multicolumn{4}{|c|}{$\begin{array}{c}\text { Effect of } \mathrm{N}, \mathrm{P}_{2} \mathrm{O}_{5} \text {, and } \mathrm{K}_{2} \mathrm{O} \text { nutrition on } \\
\text { chitinase activity }\end{array}$} & \\
\hline 1WAI & $4.53 \pm 0.39$ & $2.67 \pm 0.46$ & $11.54 \mathrm{~s}^{*}$ & 3.18 & 4.07 & 4.27 & 3.93 & 2.57 \\
\hline 4WAI & $1.57 \pm 0.26$ & $1.96 \pm 0.33$ & $5.89 \mathrm{~s}^{*}$ & 1.50 & 1.22 & 2.23 & 1.73 & 2.16 \\
\hline 8WAI & $6.37 \pm 0.76$ & $4.36 \pm 0.52$ & $8.34 \mathrm{~s}^{*}$ & $3.80^{c}$ & $3.67^{\mathrm{c}}$ & $3.68^{\mathrm{a}}$ & $6.03^{\mathrm{ab}}$ & $5.65^{\mathrm{b}}$ \\
\hline \multirow[t]{2}{*}{ 12WAI } & $3.28 \pm 0.63$ & $2.28 \pm 0.39$ & $5.16 \mathrm{~s}^{*}$ & $2.32^{\mathrm{b}}$ & $2.16^{\mathrm{b}}$ & $4.97^{\mathrm{a}}$ & $2.75^{\mathrm{b}}$ & $1.73^{\mathrm{b}}$ \\
\hline & \multicolumn{3}{|c|}{ PAL activity } & \multicolumn{4}{|c|}{$\begin{array}{c}\text { Effect of } \mathrm{N}, \mathrm{P}_{2} \mathrm{O}_{5} \text {, and } \mathrm{K}_{2} \mathrm{O} \text { nutrition on } \\
\text { PAL activity }\end{array}$} & \\
\hline 1WAI & $10.9 \pm 0.89$ & $8.90 \pm 0.64$ & $13.87 \mathrm{~s}^{*}$ & $6.67^{c}$ & $8.85^{\mathrm{bc}}$ & $11.30^{\mathrm{ab}}$ & $10.25^{\mathrm{ab}}$ & $12.45^{\mathrm{a}}$ \\
\hline 4WAI & $12.08 \pm 1.27$ & $8.96 \pm 0.77$ & $11.58 \mathrm{~s}^{*}$ & $7.75^{\mathrm{c}}$ & $7.50^{c}$ & $16.15^{\mathrm{a}}$ & $9.65^{\mathrm{bc}}$ & $11.55^{\mathrm{b}}$ \\
\hline 8WAI & $8.86 \pm 0.90$ & $5.66 \pm 0.48$ & $11.72 \mathrm{~s}^{*}$ & $5.25^{\mathrm{b}}$ & $8.00^{\mathrm{ab}}$ & $8.35^{\mathrm{a}}$ & $7.15^{\mathrm{ab}}$ & $7.55^{\mathrm{ab}}$ \\
\hline \multirow[t]{2}{*}{ 12WAI } & $10.28 \pm 1.33$ & $4.4 \pm 0.46$ & $9.47 \mathrm{~s}^{*}$ & $4.10^{\mathrm{b}}$ & $4.55^{\mathrm{b}}$ & $10.81^{\mathrm{a}}$ & $8.88^{\mathrm{a}}$ & $8.37^{\mathrm{a}}$ \\
\hline & \multicolumn{2}{|c|}{ POX activity } & & \multicolumn{4}{|c|}{$\begin{array}{c}\text { Effect of } \mathrm{N}, \mathrm{P}_{2} \mathrm{O}_{5} \text {, and } \mathrm{K}_{2} \mathrm{O} \text { nutrition and } \\
\text { BSR on POX Activity }\end{array}$} & \\
\hline 1WAI & $20.65 \pm 1.42$ & $11.64 \pm .91$ & $12.82 \mathrm{~s}^{*}$ & $15.55^{\mathrm{b}}$ & $11.80^{c}$ & $15.75^{\mathrm{b}}$ & $19.26^{\mathrm{a}}$ & $18.35^{\mathrm{ab}}$ \\
\hline 4WAI & $13.52 \pm 1.74$ & $9.96 \pm 1.51$ & $6.60 \mathrm{~s}^{*}$ & $4.20^{\mathrm{c}}$ & $13.90^{\mathrm{ab}}$ & $15.25^{\mathrm{a}}$ & $12.25^{\mathrm{b}}$ & $12.1^{\mathrm{b}}$ \\
\hline 8WAI & $6.86 \pm 0.85$ & $6.8 \pm 0.40$ & $16.74 \mathrm{~s}^{*}$ & $6.50^{\mathrm{a}}$ & $5.35^{\mathrm{a}}$ & $7.35^{\mathrm{a}}$ & $6.95^{\mathrm{a}}$ & $8.00^{\mathrm{a}}$ \\
\hline 12WAI & $12.86 \pm 1.43$ & $14.82 \pm .94$ & $15.74 \mathrm{~s}^{*}$ & $11.50^{\mathrm{c}}$ & $15.35^{\mathrm{ab}}$ & $17.35^{\mathrm{a}}$ & $11.95^{\mathrm{bc}}$ & $13.05^{\mathrm{bc}}$ \\
\hline
\end{tabular}

Note. values are the means of three replicates; $\mathrm{s}^{*}$ indicates highly significant according to $T$-test at $\alpha^{\prime}=0.05$. WAI: week after inoculation; all the $t$-values are highly significant at $0.001 \%$. Means with the same letter at a given parameter are not significantly different according to Duncan's Multiple Range Test (DMRT) at $\alpha=0.05$; values are the means of three replicates \pm standard error. Treatments: $\mathrm{T} 2=\mathrm{N} 3+\mathrm{BF}+$ Ganoderma; $\mathrm{T} 5=\mathrm{K} 1+\mathrm{BF}+$ Ganoderma; $6=\mathrm{K} 3+\mathrm{BF}+$ Ganoderma $; \mathrm{T} 8=\mathrm{N} 2 \mathrm{P} 2 \mathrm{~K} 2+\mathrm{BF}+$ Ganoderma $; \mathrm{T} 10=$ control (compound fertilizer $)+\mathrm{BF}+$ Ganoderma .

reversed phase liquid chromatography with Mass-Spec (LCMS) system, using C-18 reversed phase chromatography and negative electrospray ionization. About five $\mu \mathrm{m}$ of the extract was injected and separated using a binary gradient of ultrapure water and acetonitrile, both acidified with $0.1 \%$ formic acid, with flow rate of $0.19 \mathrm{~mL} / \mathrm{min}$.

\section{Results}

\subsection{Biochemical Analysis Assays}

3.1.1. Glucanase Activity. Glucanase enzyme activity showed high significant difference $(p<0.05)$ between the Ganoderma infected seedlings and control from week 1 to week 12 with $t$-value of $10.43,6.74,11.06$, and $8.66 \mathrm{U} \mathrm{mL}^{-1}$ at 1 to 12 WAI, respectively (Table 3 ). The relatively low content of the uninfected seedlings is a reflection of the relatively low resistance towards $G$. boninense in the nutrient level studied. The time of defense related response induction was rapid, within week 1 and week 8 , for $\beta$-1,3-glucanase in all the treatments (Table 3). Significant increase $(p<0.001)$ in glucanase activity on $G$. boninense-RWB seedlings was detected in most of the treatments at one WAI. However, T6 and $\mathrm{T} 2$ recorded great differences between control and $+\mathrm{G}$ inoculated oil palm seedlings while $\mathrm{T} 5, \mathrm{~T} 8$, and $\mathrm{T} 10$ recorded slight changes among the treatments. By week 8 , glucanase activity of T6 was dramatically higher, about 5-fold higher than untreated seedlings (Figure 1), as a sign of activated glucanase enzyme activity. However, $\beta$-1,3-glucanases are induced not only by pathogen infection, but also by other factors. Except for T10, at 12 WAI, the glucanase activity of all G. boninense seedlings of T2, T5, T6, and T8 was decreased gradually compared to the other treatments. However, result of OD recorded at 1,8 , and 12 WAI for glucanase activity of the G. boninense-RWB seedlings was notably higher than the control.

Chitinase Activity. A highly significant difference was found between the chitinase Ganoderma treatments and control from week 1 to week 12 with $t$-value of $11.54,5.89,8.34$, and 


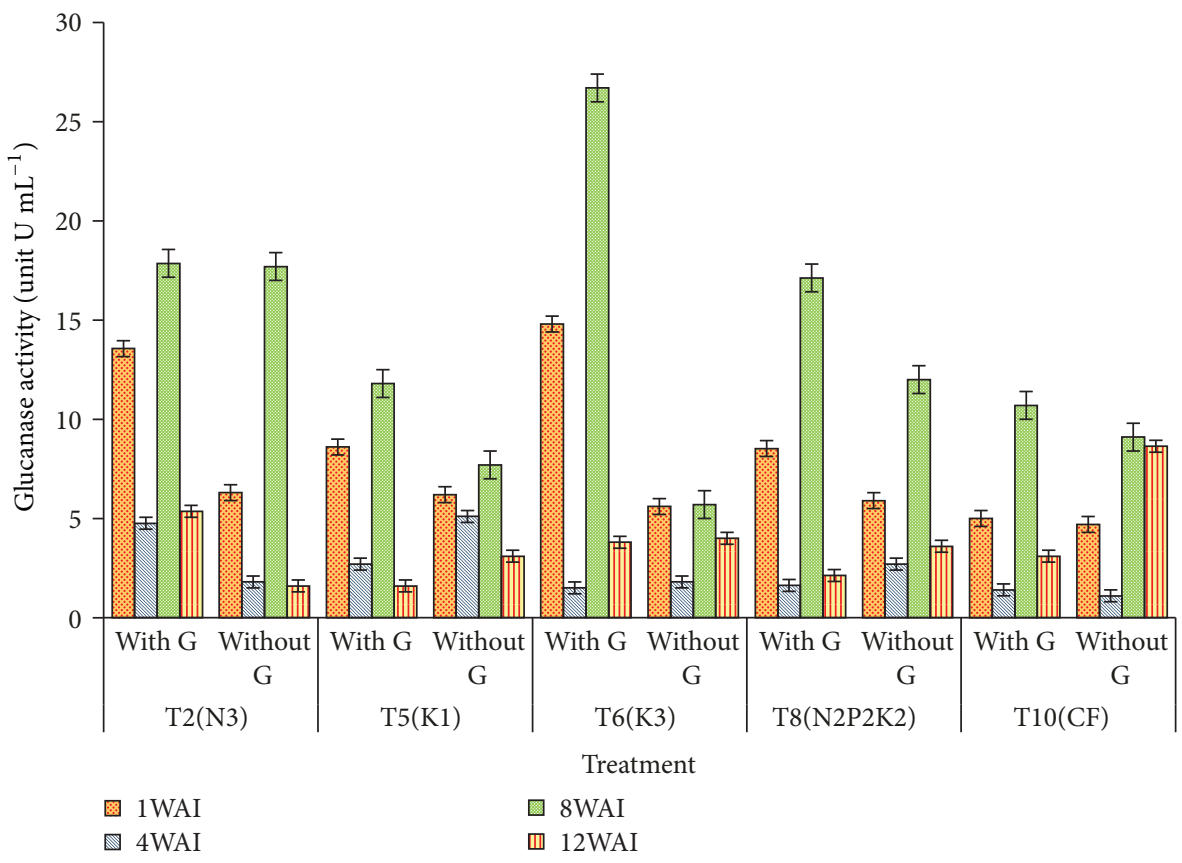

Figure 1: Effect of different levels of N, P, and K on glucanase activity in oil palm roots. Note. Values are the means of three replicates. Error bars represent the standard error. WAI: week after inoculation.

$5.16 \mathrm{U} \mathrm{mL}^{-1}$ for week 1 to week 12 , respectively (Table 3 ). Although the level of chitinase increased in the Ganoderma infected seedlings during the study duration, it appeared that it was not sufficiently high, had not reached effective levels, or was too late to stop the fungal from growth.

Significant differences were observed at 8 to 12 WAI with T6 and T8 recording markedly higher enzyme activities compared to other treatments. Relatively low levels of chitinase were detected initially at 4 WAI for all different treatments and only began to produce higher levels of the enzyme at week 8 in both T6 and T8 and at week 12 in T6 when they were subjected to Ganoderma attack. Although, relatively high levels of chitinase were observed in most treatments at 1 WAIT, it does not seem to be vital for plants at the initial time period of treatment. The present results indicated that time of defense related response induction was at weeks 8 and 12 in T6 and at week 8 in almost all the treatments except T2 and T5. Treatments T6 and T8 at 8 WAI recorded the highest values of the chitinase activity. However, T2 recorded lower chitinase activity for $+\mathrm{G}$ inoculated seedlings treatments when compared to T6 and T8 (Figure 2). The low chitinase activity in T2 may be the cause of defense failure in the event of Ganoderma infection. All uninoculated seedlings from the uninoculated treatment, recorded lesser chitinase activity as compared to Ganoderma-inoculated treatment, which revealed a positive relationship at $p<0.05$ between chitinase activity and $G$. boninense infected seedlings.

Phenylalanine Ammonia-Lyase Activity. High significant difference was found between the PAL Ganoderma treatment and control from week 1 to week 12 with $t$-value of $13.87,11.58$, 11.72 , and 9.47 for week 1 to week 12 , respectively (Table 3 ). The PAL activity measured in the roots of infected palms revealed highly significant differences among treatments $(p<0.0001)$. The highest activity was observed in the infected roots of T6, followed by $\mathrm{T} 8$ and T10 with no significant difference between them, while the lowest was detected in T2. This could indicate that at this stage more phenolics including lignin were synthesized in T6, T8, and T10 and are more tolerant compared to T2 (Figure 3).

Peroxidase Activity. High significant difference was found between the Ganoderma treatment and control from week 1 to week 12 with $t$-value of $12.82,6.60,16.74$, and 15.74, respectively. Higher POX was expressed in T8 at 1 WAI, but T6 showed higher POX activities from 8 WAI to 12 WAI. The lowest POX activity in the root was in sample T2 (Table 3). The results obtained have shown that T6 significantly gave high value for enzyme POX activity. However, at 1 WAI, T8 was the highest followed by T10, an indication of a fast and rapid induction of POX at the beginning of infection. However, at 4, 8, and 12 WAI, T6 gave the highest POX activity and was significantly higher in all infected root tissues. At 8 WAI, all POX activities were not significantly different among the Ganoderma infected root tissues for POX enzymes. Glucanase, POX (weeks 1 and 4), and PAL activities were stimulated by the Ganoderma infection within 1 week, recurring at week 8 , and chitinase within week 8 after treatment application (Figure 4).

Metabolite Compounds of Uninfected and Infected Oil Palm Seedlings. Several metabolite compounds were detected in uninfected and infected seedlings treated with different levels of $\mathrm{N}, \mathrm{P}$, and $\mathrm{K}$ fertilizer. However, only known compounds are listed here to study more details and find interaction between effect of pathogen and fertilizer (Table 4). There was 




Figure 2: Effect of different levels of $\mathrm{N}, \mathrm{P}_{2} \mathrm{O}_{5}$, and $\mathrm{K}_{2} \mathrm{O}$ on chitinase activity in oil palm roots. Note. Values are the means of three replicates. Error bars represent the standard error. WAI: week after inoculation.

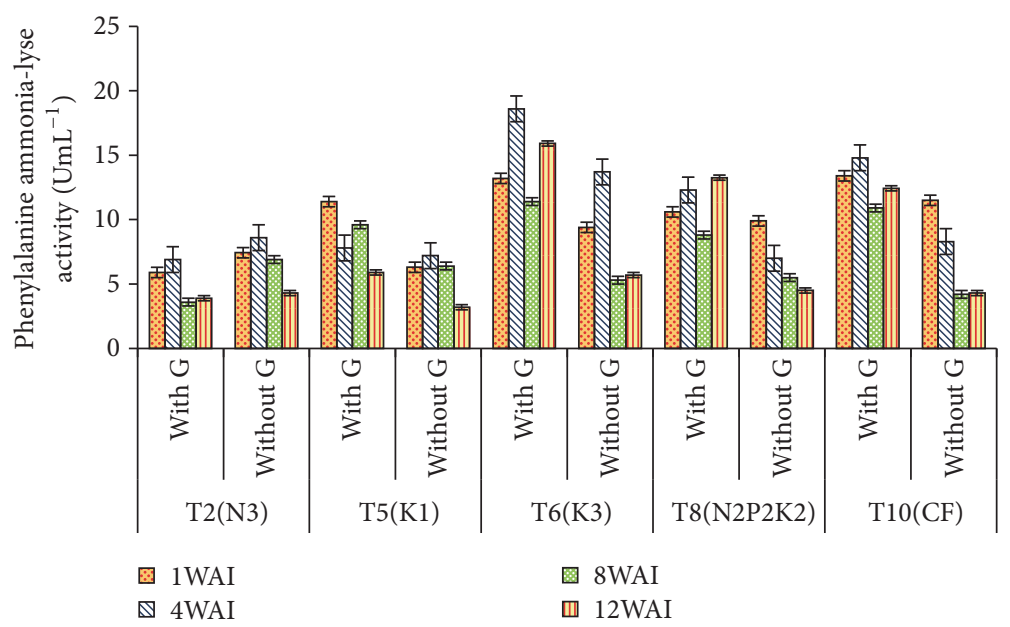

FIGURE 3: Effect of different levels of $\mathrm{N}, \mathrm{P}_{2} \mathrm{O}_{5}$, and $\mathrm{K}_{2} \mathrm{O}$ on PAL activity in oil palm roots. Note. Values are the means of three replicates. Error bars represent the standard error. WAI: week after inoculation.

a big difference observed in the number of released metabolite compounds between uninfected/infected samples with different $\mathrm{N}, \mathrm{P}$, and $\mathrm{K}$ treatments most probably due to alteration in antioxidant enzyme activities. For instance, forty compounds were obtained from uninfected sample T1 with basal fertilizer (BF) and low $\mathrm{N}$ fertilizer, while only three compounds were extracted from the same fertilized sample $\mathrm{T} 1$ infected with Ganoderma. One and five compounds were observed, respectively, from uninfected and infected sample $\mathrm{T} 2$ with $\mathrm{BF}$ and high $\mathrm{N}$ fertilizer. One compound was obtained from uninfected sample $\mathrm{T} 3$ with basic fertilizer (BF) and low $\mathrm{P}$ fertilizer, while 18 compounds were extracted from the same fertilized sample T3 infected with Ganoderma. One and 13 compounds were observed, respectively, from uninfected and infected sample T4 with BF and high P fertilizer. Two compounds were obtained from uninfected sample T5 


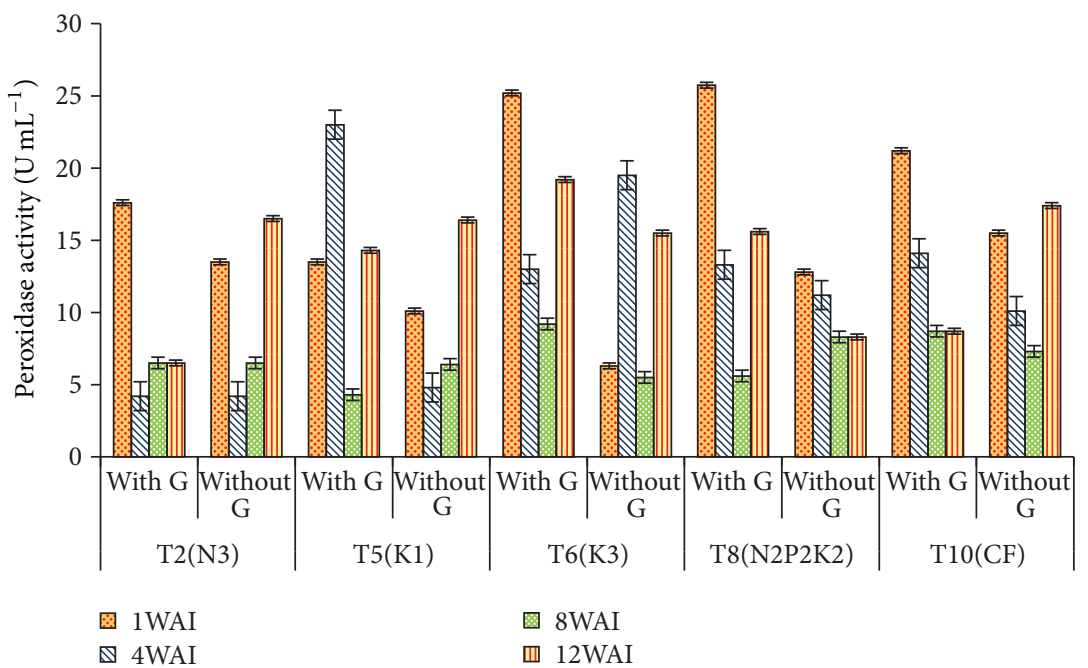

Figure 4: Effect of different levels of $\mathrm{N}, \mathrm{P}_{2} \mathrm{O}_{5}$, and $\mathrm{K}_{2} \mathrm{O}$ on POX activity in oil palm roots. Note. Values are the means of three replicates. Error bars represent the standard error. WAI: week after inoculation.

with basic fertilizer (BF) and low $\mathrm{K}$ fertilizer, while nine compounds were extracted from the same fertilized sample T5 infected with Ganoderma. Four and two compounds were observed, respectively, from uninfected and infected sample T6 with BF and high $\mathrm{K}$ fertilizer.

Three compounds were obtained from uninfected sample T7 with basic fertilizer (BF) treated with N1P1 K1 (N low, P low, K low), while ten compounds were extracted from the same fertilized sample T7 infected with Ganoderma. Two compounds were obtained from uninfected sample T8 with basal fertilizer (BF) treated with N2P2 K2 (N optimum, P optimum, K optimum), while five compounds were extracted from the same fertilized sample T8 infected with Ganoderma. Thirty-one compounds were obtained from uninfected sample T9 with basic fertilizer (BF) treated with N3P3 K3 (N high, $\mathrm{P}$ high, $\mathrm{K}$ high), whereas unknown compounds were identified from the same fertilized sample T9 infected with Ganoderma. Finally, twenty-six compounds were obtained from uninfected sample T10 with basic fertilizer (BF) and 14 compounds were extracted from the same fertilized sample T10 infected with Ganoderma. The number of detected known metabolite compounds differs among infected and uninfected samples. For instance, the number of known compounds extracted from uninfected sample T1, T6, T9, and T10 was higher than that from infected ones, while the number of compounds extracted from infected samples T2, T3, T4, T5, T7, T8 was higher than that from uninfected ones.

The dendrogram and fan plot produced by hierarchal cluster analysis (HCA) of the different fertilized oil palm seedlings, based on a common molecular mass deduced from the recorded $m / z$ value and similar retention time (RT) and peak shape (Figures 5 and 6), provided a more detailed view on the relationships between treatments. The HCA distinguished two major clusters for treatments denoted as A and B. Cluster A consist of [T2, T6, T8, T10] with the higher enzyme activities among other treatments. Cluster B contained two subgroups: one consisting of [T1, T3, T9] and a second one consisting of [T4, T5, T7]. The HCA of the set of 190 metabolite compounds revealed the presence of several metabolite groups, arbitrarily denoted with A to D, characterized by their particular expression pattern across the ten treatments (Figure 6). Although there is no direct evidence to show the extent of plant enzymes contributing to the resistance at the infection site because they are interacted by various factors and encoded by multigene family, a previous considerable research provided corroborative evidence that plant chitinase and $\beta$-1,3-glucanases in plant self-defense mechanism (Figure 7) illustrate how optimum NPK nutrients might either mutate the production of glucanase, chitinase, POX, and PAL activities or be involved in secondary metabolite profiling for basal resistance in oil palm.

\section{Discussion}

Induction of $\beta$-1,3-glucanases and other PR proteins in the plant can also occur due to some components of pathogens or degraded components of pathogens. These elicitors may be components of the cell surface of the pathogen that are released by host enzymes, including fungal $\beta$-glucan, chitin, chitosan, glycoproteins, and N-acetyl- chitooligosaccharides $[21,22]$. They may also be synthesized and released by the pathogen after it enters the host in response to host signals. In view of the obtained results from chitinase assay in this study, it appears likely that chitinase plays a role in the interaction between Ganoderma and nutrition of the oil palm seedlings. As pointed out by other researchers [23, 24], the early and massive induction of chitinase activity is generally related to the increased resistance of plant tissues to infection by pathogens. However, at week 12, the chitinases activity was significantly decreased with the increase in time over the study period, an indication that the enzyme activities were short-lasting. This has been supported previously by the fact that defense mechanisms are often activated late in the infection process when the pathogen had colonized the tissue 
TABLE 4: Mass spectrometry for each compound and its molecular structure observed in different N, P, K combination of Ganoderma inoculated $(+)$ and uninoculated oil palm seedlings.

\begin{tabular}{|c|c|c|c|c|c|c|}
\hline Sample & Ganoderma & RT & $m / z$ & Mass & Name & Molecular formula \\
\hline $\mathrm{T} 1$ & $(-)$ & 0.87 & 175.119 & 174.112 & Arginine & C6 H14 N4 O2 \\
\hline $\mathrm{T} 1$ & $(-)$ & 0.92 & 104.107 & 103.1 & 2-Amino-3-methyl-1-butanol & C5 H13 N O \\
\hline $\mathrm{T} 1$ & $(-)$ & 1 & 293.066 & 254.101 & Dyphylline & C10 H14 N4 O4 \\
\hline $\mathrm{T} 1$ & $(-)$ & 1.01 & 203.054 & 180.065 & Theobromine & C7 H8 N4 O2 \\
\hline $\mathrm{T} 1$ & $(-)$ & 1.02 & 435.062 & 180.065 & 4-Hydroxylevamisole glucuronide & $\mathrm{C} 17 \mathrm{H} 20 \mathrm{~N} 2 \mathrm{O} 7 \mathrm{~S}$ \\
\hline $\mathrm{T} 1$ & $(-)$ & 1.13 & 220.134 & 180.065 & Meperidinic acid & C13 H17 N O2 \\
\hline $\mathrm{T} 1$ & $(-)$ & 1.2 & 268.155 & 180.065 & Metoprolol acid & C14 H21 N O4 \\
\hline $\mathrm{T} 1$ & $(-)$ & 1.24 & 206.119 & 180.065 & Normeperidinic acid & C12 H15 N O2 \\
\hline $\mathrm{T} 1$ & $(-)$ & 1.25 & 282.171 & 180.065 & $\begin{array}{l}\text { Benzenepropanoic acid, 4-[2-hydroxy-3- } \\
\text { [(1-methylethyl)amino]propoxy]-(9CI) ASL } \\
8123\end{array}$ & C15 H23 N O4 \\
\hline $\mathrm{T} 1$ & $(-)$ & 1.93 & 417.18 & 180.065 & S-adenosylmethionine & C15 H23 N6 O5 S \\
\hline $\mathrm{T} 1$ & $(-)$ & 1.96 & 362.209 & 180.065 & Phe Pro Val & C19 H27 N3 O4 \\
\hline $\mathrm{T} 1$ & $(-)$ & 2.18 & 234.15 & 180.065 & Normeperidine & C14 H19 N O2 \\
\hline $\mathrm{T} 1$ & $(-)$ & 2.23 & 409.185 & 180.065 & Asn Met Gln & C14 H25 N5 O6 S \\
\hline $\mathrm{T} 1$ & $(-)$ & $2.31^{\circ}$ & 409.185 & 180.065 & Asn Met Gln & C14 H25 N5 O6 S \\
\hline $\mathrm{T} 1$ & $(-)$ & 2.89 & 480.226 & 180.065 & Gln Phe Trp & C25 H29 N5 O5 \\
\hline $\mathrm{T} 1$ & $(-)$ & 3.17 & 236.166 & 180.065 & 5,7,9,11,13-tetradecapentaenoic acid & C14 H18 O2 \\
\hline $\mathrm{T} 1$ & $(-)$ & 3.23 & 480.224 & 180.065 & Gln Phe Trp & C25 H29 N5 O5 \\
\hline $\mathrm{T} 1$ & $(-)$ & 3.47 & 601.154 & 180.065 & Rhoifolin & C27 H30 O14 \\
\hline $\mathrm{T} 1$ & $(-)$ & 4.71 & 393.19 & 180.065 & Trp Gly Asn & C17 H21 N5 O5 \\
\hline $\mathrm{T} 1$ & $(-)$ & 4.89 & 541.263 & 180.065 & $\begin{array}{l}\text { 17-Alpha, } \\
\text { 21-dihydroxy-11,20-dioxo-5-beta-pregnan- } \\
\text { 3-alpha-yl-beta-d-glucuronide }\end{array}$ & C27 H40 O11 \\
\hline $\mathrm{T} 1$ & $(-)$ & 5.26 & 395.205 & 180.065 & Tyr Gly Arg & C17 H26 N6 O5 \\
\hline $\mathrm{T} 1$ & $(-)$ & 9.75 & 246.243 & 180.065 & 4,8-Dimethyl-dodecanoic acid & $\mathrm{C} 14 \mathrm{H} 28 \mathrm{O} 2$ \\
\hline $\mathrm{T} 1$ & $(-)$ & 12.1 & 274.275 & 180.065 & C16 sphinganine & C16 H35 N O2 \\
\hline $\mathrm{T} 1$ & $(-)$ & 12.1 & 274.275 & 180.065 & C16 sphinganine & C16 H35 N O2 \\
\hline $\mathrm{T} 1$ & $(-)$ & 12.2 & 230.249 & 180.065 & Myristaldehyde & $\mathrm{C} 14 \mathrm{H} 28 \mathrm{O}$ \\
\hline $\mathrm{T} 1$ & $(-)$ & 12.2 & 318.301 & 180.065 & Phytosphingosine & C18 H39 N O3 \\
\hline $\mathrm{T} 1$ & $(-)$ & 12.2 & 288.291 & 180.065 & C17 sphinganine & C17 H37 N O2 \\
\hline $\mathrm{T} 1$ & $(-)$ & 12.4 & 288.291 & 180.065 & C17 sphinganine & C17 H37 N O2 \\
\hline $\mathrm{T} 1$ & $(-)$ & 12.6 & 272.259 & 180.065 & 2R-aminohexadecanoic acid & C16 H33 N O2 \\
\hline $\mathrm{T} 1$ & $(-)$ & 12.8 & 288.291 & 180.065 & C17 Sphinganine & C17 H37 N O2 \\
\hline $\mathrm{T} 1$ & $(-)$ & 13.2 & 288.291 & 180.065 & C17 Sphinganine & C17 H37 N O2 \\
\hline $\mathrm{T} 1$ & $(-)$ & 13.3 & 244.265 & 180.065 & 9-Pentadecen-1-ol & $\mathrm{C} 15 \mathrm{H} 30 \mathrm{O}$ \\
\hline $\mathrm{T} 1$ & $(-)$ & 15 & 272.296 & 180.065 & 14-Methyl-8-hexadecen-1-ol & $\mathrm{C} 17 \mathrm{H} 34 \mathrm{O}$ \\
\hline $\mathrm{T} 1$ & $(-)$ & 15.5 & 272.296 & 180.065 & 14-Methyl-8-hexadecen-1-ol & $\mathrm{C} 17 \mathrm{H} 34 \mathrm{O}$ \\
\hline $\mathrm{T} 1$ & $(-)$ & 16.2 & 599.412 & 180.065 & Mytiloxanthin & C40 H54 O4 \\
\hline $\mathrm{T} 1$ & $(-)$ & 21.3 & 599.412 & 180.065 & Mytiloxanthin & C40 H54 O4 \\
\hline $\mathrm{T} 1$ & $(-)$ & 21.5 & 585.433 & 180.065 & Myxol & C40 H56 O3 \\
\hline $\mathrm{T} 1$ & $(-)$ & 21.5 & 601.427 & 180.065 & Capsanthin 3,6-epoxide & C40 H56 O4 \\
\hline $\mathrm{T} 1$ & $(-)$ & 21.8 & 429.374 & 180.065 & $\begin{array}{l}\text { 25-Hydroxy-26,27-dimethylvitamin D3/ } \\
\text { 25-Hydroxy-26,27-dimethylcholecalciferol }\end{array}$ & C29 H48 O2 \\
\hline $\mathrm{T} 1$ & $(-)$ & 22.1 & 167.01 & 180.065 & 6-Hydroxy-2-hexynoic acid & C6 H8 O3 \\
\hline $\mathrm{T} 1$ & $(+)$ & 8.79 & 213.145 & 180.065 & meglumine & C7 H17 N O5 \\
\hline
\end{tabular}


TABLE 4: Continued.

\begin{tabular}{|c|c|c|c|c|c|c|}
\hline Sample & Ganoderma & $\mathrm{RT}$ & $m / z$ & Mass & Name & Molecular formula \\
\hline $\mathrm{T} 1$ & $(+)$ & 17.8 & 248.198 & 180.065 & Leu Val & $\mathrm{C} 11 \mathrm{H} 22 \mathrm{~N} 2 \mathrm{O} 3$ \\
\hline $\mathrm{T} 1$ & $(+)$ & 17.8 & 192.135 & 180.065 & Lupinine & C10 H19 N O \\
\hline $\mathrm{T} 2$ & $(-)$ & 21.92 & 125.039 & 248.064 & Asp Asp & C8 H12 N2 O7 \\
\hline $\mathrm{T} 2$ & $(+)$ & 1.06 & 300.148 & 299.14 & Metoclopramide & $\mathrm{C} 14 \mathrm{H} 22 \mathrm{Cl} \mathrm{N} 3 \mathrm{O} 2$ \\
\hline $\mathrm{T} 2$ & $(+)$ & 1.17 & 300.148 & 299.141 & Metoclopramide & $\mathrm{C} 14 \mathrm{H} 22 \mathrm{Cl} \mathrm{N} 3 \mathrm{O} 2$ \\
\hline $\mathrm{T} 2$ & $(+)$ & 2.28 & 409.187 & 408.18 & Trp Phe Gly & C22 H24 N4 O4 \\
\hline $\mathrm{T} 2$ & $(+)$ & 5.24 & 395.208 & 356.246 & Dopexamine & $\mathrm{C} 22 \mathrm{H} 32 \mathrm{~N} 2 \mathrm{O} 2$ \\
\hline $\mathrm{T} 2$ & $(+)$ & 17.77 & 243.139 & 242.132 & $6 \mathrm{E}, 8 \mathrm{E}, 14 \mathrm{E}-$ hexadecatriene-10,12-diynoic acid & $\mathrm{C} 16 \mathrm{H} 18 \mathrm{O} 2$ \\
\hline T3 & $(-)$ & 22.09 & 102.971 & 64.0082 & Ethyl chloride & $\mathrm{C} 2 \mathrm{H} 5 \mathrm{Cl}$ \\
\hline $\mathrm{T} 3$ & $(+)$ & 0.26 & 257.975 & 219.011 & $\begin{array}{l}\text { 4-Amino-3-(5-chlorothien-2-YL) Butanoic } \\
\text { acid }\end{array}$ & $\mathrm{C} 8 \mathrm{H} 10 \mathrm{Cl}$ N O2 S \\
\hline T3 & $(+)$ & 0.97 & 293.066 & 254.103 & Dyphylline & C10 H14 N4 O4 \\
\hline T3 & $(+)$ & 0.98 & 219.028 & 180.065 & Theobromine & $\mathrm{C} 7 \mathrm{H} 8 \mathrm{~N} 4 \mathrm{O} 2$ \\
\hline T3 & $(+)$ & 1 & 277.0914 & 254.102 & Dyphylline & C10 H14 N4 O4 \\
\hline T3 & $(+)$ & 1.01 & 203.055 & 180.065 & Theobromine & C7 H8 N4 O2 \\
\hline T3 & $(+)$ & 1.03 & 435.061 & 396.097 & 4-Hydroxylevamisole glucuronide & $\mathrm{C} 17 \mathrm{H} 20 \mathrm{~N} 2 \mathrm{O} 7 \mathrm{~S}$ \\
\hline T3 & $(+)$ & 2 & 362.244 & 344.21 & Oxyphencyclimine & $\mathrm{C} 20 \mathrm{H} 28 \mathrm{~N} 2 \mathrm{O} 3$ \\
\hline T3 & $(+)$ & 2.27 & 409.187 & 408.18 & Trp Phe Gly & $\mathrm{C} 22 \mathrm{H} 24 \mathrm{~N} 4 \mathrm{O} 4$ \\
\hline T3 & $(+)$ & 2.9 & 480.227 & 479.219 & Gln Phe Trp & C25 H29 N5 O5 \\
\hline T3 & $(+)$ & 3.24 & 480.226 & 479.219 & Gln Phe Trp & C25 H29 N5 O5 \\
\hline T3 & $(+)$ & 3.63 & 264.161 & 246.127 & Santonin & $\mathrm{C} 15 \mathrm{H} 18 \mathrm{O} 3$ \\
\hline T3 & $(+)$ & 5.26 & 395.207 & 377.174 & Gln Lys Cys & C14 H27 N5 O5 S \\
\hline T3 & $(+)$ & 12.07 & 274.275 & 273.268 & C16 Sphinganine & C16 H35 N O2 \\
\hline T3 & $(+)$ & 12.49 & 409.16 & 370.197 & Lys His Ser & C15 H26 N6 O5 \\
\hline T3 & $(+)$ & 16 & 243.134 & 242.126 & Hydroxyamobarbital & C11 H18 N2 O4 \\
\hline T3 & $(+)$ & 18.2 & 419.243 & 418.236 & Met Arg Leu & C17 H34 N6 O4 S \\
\hline T3 & $(+)$ & 18.22 & 419.279 & 418.272 & Simvastatin & C25 H38 O5 \\
\hline T3 & $(+)$ & 18.23 & 375.253 & 374.245 & Digitoxigenin & C23 H34 O4 \\
\hline $\mathrm{T} 4$ & $(-)$ & 16.01 & 243.133 & 242.126 & Hydroxyamobarbital & C11 H18 N2 O4 \\
\hline $\mathrm{T} 4$ & $(+)$ & 0.99 & 277.091 & 254.102 & Dyphylline & C10 H14 N4 O4 \\
\hline $\mathrm{T} 4$ & $(+)$ & 1.01 & 138.058 & 120.025 & Sulfolane & $\mathrm{C} 4 \mathrm{H} 8 \mathrm{O} 2 \mathrm{~S}$ \\
\hline $\mathrm{T} 4$ & $(+)$ & 1.95 & 362.243 & 344.209 & Oxyphencyclimine & C20 H28 N2 O3 \\
\hline $\mathrm{T} 4$ & $(+)$ & 2.25 & 409.186 & 408.178 & Trp Phe Gly & C22 H24 N4 O4 \\
\hline $\mathrm{T} 4$ & $(+)$ & 2.86 & 480.226 & 479.218 & Gln Phe Trp & C25 H29 N5 O5 \\
\hline $\mathrm{T} 4$ & $(+)$ & 3.2 & 480.226 & 479.219 & Gln Phe Trp & C25 H29 N5 O5 \\
\hline $\mathrm{T} 4$ & $(+)$ & 3.44 & 601.156 & 578.166 & Rhoifolin & C27 H30 O14 \\
\hline $\mathrm{T} 4$ & $(+)$ & 5.23 & 395.207 & 377.173 & Gln Lys Cys & C14 H27 N5 O5 S \\
\hline $\mathrm{T} 4$ & $(+)$ & 12.06 & 274.275 & 273.268 & C16 sphinganine & C16 H35 N O2 \\
\hline $\mathrm{T} 4$ & $(+)$ & 12.18 & 318.3 & 317.292 & Phytosphingosine & C18 H39 N O3 \\
\hline $\mathrm{T} 4$ & $(+)$ & 12.48 & 409.163 & 386.174 & Lys Cys His & C15 H26 N6 O4 S \\
\hline $\mathrm{T} 4$ & $(+)$ & 18.19 & 419.279 & 418.271 & Simvastatin & C25 H38 O5 \\
\hline $\mathrm{T} 4$ & $(+)$ & 21.49 & 585.433 & 584.426 & Myxol & $\mathrm{C} 40 \mathrm{H} 56 \mathrm{O} 3$ \\
\hline T5 & $(-)$ & 22.61 & 179.988 & 141.025 & 5-Acetyl-4-methylthiazole & C6 H7 N O S \\
\hline T5 & $(-)$ & 22.93 & - & 141.025 & 5-Acetyl-4-methylthiazole & C6 H7 N O S \\
\hline T5 & $(+)$ & 1.35 & 167.01 & 128.047 & 6-Hydroxy-2-hexynoic acid & C6 H8 O3 \\
\hline T5 & $(+)$ & 17.76 & 248.196 & 230.162 & Leu Val & $\mathrm{C} 11 \mathrm{H} 22 \mathrm{~N} 2 \mathrm{O} 3$ \\
\hline T5 & $(+)$ & 17.77 & 192.136 & 169.147 & Lupinine & C10 H19 N O \\
\hline T5 & $(+)$ & 21.45 & 411.2875 & 410.2796 & 24,25-epoxy-1 alpha-hydroxy-22,22 & C27 H38 O3 \\
\hline T5 & $(+)$ & 21.46 & 343.2247 & 320.2348 & $(+/-) 14,15-\mathrm{EpETrE}$ & $\mathrm{C} 20 \mathrm{H} 32 \mathrm{O} 3$ \\
\hline
\end{tabular}


TABle 4: Continued.

\begin{tabular}{|c|c|c|c|c|c|c|}
\hline Sample & Ganoderma & RT & $m / z$ & Mass & Name & Molecular formula \\
\hline T5 & $(+)$ & 21.48 & 479.3497 & 456.3595 & Testosterone undecanoate & $\mathrm{C} 30 \mathrm{H} 48 \mathrm{O} 3$ \\
\hline T5 & $(+)$ & 21.65 & 343.2245 & 320.2353 & $(+/-) 14,15-\mathrm{EpETrE}$ & C20 H32 O3 \\
\hline T5 & $(+)$ & 21.66 & 411.2861 & 388.297 & $1 \alpha, 25$-Dihydroxy-23,24-dinorvitamin D3 & $\mathrm{C} 25 \mathrm{H} 40 \mathrm{O} 3$ \\
\hline T5 & $(+)$ & 21.94 & 125.0381 & 248.0616 & Dapsone & $\mathrm{C} 12 \mathrm{H} 12 \mathrm{~N} 2 \mathrm{O} 2 \mathrm{~S}$ \\
\hline T6 & $(-)$ & 17.77 & 248.1973 & 230.1635 & Leu Val & $\mathrm{C} 11 \mathrm{H} 22 \mathrm{~N} 2 \mathrm{O} 3$ \\
\hline T6 & $(-)$ & 17.78 & 243.1331 & 242.1258 & Hydroxyamobarbital & C11 H18 N2 O4 \\
\hline T6 & $(-)$ & 21.56 & 839.4909 & 821.4566 & Tacrolimus metabolite M-VIII & C43 H67 N O14 \\
\hline T6 & $(-)$ & 21.65 & 498.9004 & 497.8933 & Perflubron & C8 Br F17 \\
\hline T6 & $(+)$ & 21.66 & 498.9008 & 497.8937 & Perflubron & C8 Br F17 \\
\hline T6 & $(+)$ & 21.95 & 125.0378 & 248.0611 & Dapsone & $\mathrm{C} 12 \mathrm{H} 12 \mathrm{~N} 2 \mathrm{O} 2 \mathrm{~S}$ \\
\hline T7 & $(-)$ & 1.2 & 179.9883 & 141.0251 & 5-Acetyl-4-methylthiazole & C6 H7 N O S \\
\hline T7 & $(-)$ & 17.77 & 248.1964 & 230.1627 & Leu Val & $\mathrm{C} 11 \mathrm{H} 22 \mathrm{~N} 2 \mathrm{O} 3$ \\
\hline T7 & $(-)$ & 21.65 & 498.9009 & 497.8938 & Perflubron & C8 Br F17 \\
\hline T7 & $(+)$ & 17.51 & 301.1413 & 278.152 & Phthalic acid mono-2-ethylhexyl Ester & $\mathrm{C} 16 \mathrm{H} 22 \mathrm{O} 4$ \\
\hline T7 & $(+)$ & 17.77 & 192.1362 & 169.1473 & Lupinine & C10 H19 N O \\
\hline T7 & $(+)$ & 17.77 & 248.2013 & 247.194 & Lycopodine & $\mathrm{C} 16 \mathrm{H} 25 \mathrm{~N} \mathrm{O}$ \\
\hline T7 & $(+)$ & 20.14 & 282.2793 & 281.2721 & Oleoyl amine & C18 H35 N O \\
\hline T7 & $(+)$ & 21.44 & 411.2876 & 388.298 & $1 \alpha$-hydroxy-21-nor-20-oxavitamin D3 & $\mathrm{C} 25 \mathrm{H} 40 \mathrm{O} 3$ \\
\hline $\mathrm{T} 7$ & $(+)$ & 21.45 & 343.2242 & 320.235 & $(+/-) 14,15-\mathrm{EpETrE}$ & C20 H32 O3 \\
\hline $\mathrm{T} 7$ & $(+)$ & 21.62 & 343.224 & 320.2347 & $(+/-) 14,15-E p E T r E$ & C20 H32 O3 \\
\hline $\mathrm{T} 7$ & $(+)$ & 21.64 & 411.2862 & 388.297 & $1 \alpha, 25$-Dihydroxy-23,24-dinorvitamin D3 & $\mathrm{C} 25 \mathrm{H} 40 \mathrm{O} 3$ \\
\hline $\mathrm{T} 7$ & $(+)$ & 22.15 & 167.011 & 128.0479 & 6-Hydroxy-2-hexynoic acid & C6 $\mathrm{H} 8 \mathrm{O} 3$ \\
\hline T7 & $(+)$ & 22.74 & 179.9885 & 141.0251 & 5-Acetyl-4-methylthiazole & C6 H7 N O S \\
\hline T8 & $(-)$ & 16.01 & 243.1334 & 242.1261 & Hydroxyamobarbital & C11 H18 N2 O4 \\
\hline T8 & $(-)$ & 17.77 & 243.1333 & 242.126 & Hydroxyamobarbital & C11 H18 N2 O4 \\
\hline T8 & $(+)$ & 17.76 & 248.1967 & 230.1631 & Leu Val & $\mathrm{C} 11 \mathrm{H} 22 \mathrm{~N} 2 \mathrm{O} 3$ \\
\hline $\mathrm{T} 8$ & $(+)$ & 17.77 & 192.1347 & 174.1013 & Val Gly & C7 H14 N2 O3 \\
\hline $\mathrm{T} 8$ & $(+)$ & 21.61 & 395.2916 & 356.3286 & (+)-3-hydroxy behenic & $\mathrm{C} 22 \mathrm{H} 44 \mathrm{O} 3$ \\
\hline $\mathrm{T} 8$ & $(+)$ & 21.67 & 909.5463 & 886.5559 & Glc-GP(18:0/20:4(5Z,8Z,11Z,14Z)) & C47 H83 O13 P \\
\hline T8 & $(+)$ & 21.93 & 125.0388 & 248.0632 & Dapsone & $\mathrm{C} 12 \mathrm{H} 12 \mathrm{~N} 2 \mathrm{O} 2 \mathrm{~S}$ \\
\hline T9 & $(-)$ & 0.92 & 104.1065 & 103.0992 & 2-Amino-3-methyl-1-butanol & C5 H13 N O \\
\hline T9 & $(-)$ & 0.97 & 176.0109 & 137.0479 & p-aminobenzoic acid & C7 H7 N O2 \\
\hline T9 & $(-)$ & 0.98 & 293.0644 & 254.1012 & Dyphylline & C10 H14 N4 O4 \\
\hline T9 & $(-)$ & 0.99 & 160.0375 & 137.0483 & 3-Pyridylacetic acid & C7 H7 N O2 \\
\hline T9 & $(-)$ & 1.02 & 203.0545 & 180.0654 & Theobromine & $\mathrm{C} 7 \mathrm{H} 8 \mathrm{~N} 4 \mathrm{O} 2$ \\
\hline T9 & $(-)$ & 1.03 & 435.0635 & 396.0998 & 4-Hydroxylevamisole glucuronide & C17 H20 N2 O7 S \\
\hline T9 & $(-)$ & 1.05 & 265.0252 & 226.0621 & Anthralin & $\mathrm{C} 14 \mathrm{H} 10 \mathrm{O} 3$ \\
\hline T9 & $(-)$ & 1.13 & 230.0935 & 191.1302 & Diethyltoluamide & C12 H17 N O \\
\hline T9 & $(-)$ & 1.19 & 287.1111 & 264.122 & 1-(5-Ketohexyl)-3-methylxanthine & $\mathrm{C} 12 \mathrm{H} 16 \mathrm{~N} 4 \mathrm{O} 3$ \\
\hline T9 & $(-)$ & 1.21 & 268.1553 & 267.1479 & Metoprolol acid & $\mathrm{C} 14 \mathrm{H} 21 \mathrm{~N} \mathrm{O} 4$ \\
\hline T9 & $(-)$ & 1.26 & 282.1712 & 281.1639 & Benzenepropanoic acid & $\mathrm{C} 15$ H23 N O4 \\
\hline T9 & $(-)$ & 1.98 & 362.2078 & 361.2005 & Phe Val Pro & C19 H27 N3 O4 \\
\hline T9 & $(-)$ & 2.03 & 362.242 & 344.2085 & Oxyphencyclimine & C20 H28 N2 O3 \\
\hline T9 & $(-)$ & 2.28 & 411.2 & 388.2101 & $\begin{array}{l}\text { Methyl 10,12,13,15-bisepidioxy- } \\
\text { 16-Hydroperoxy-8E-octadecenoate }\end{array}$ & C19 H32 O8 \\
\hline T9 & $(-)$ & 2.28 & 409.185 & 391.1507 & Asn Met Gln & C14 H25 N5 O6 S \\
\hline T9 & $(-)$ & 2.45 & 621.217 & 620.2091 & Diethylstilbestrol diglucuronide & C30 H36 O14 \\
\hline T9 & $(-)$ & 2.89 & 480.225 & 479.2173 & Gln Phe Trp & C25 H29 N5 O5 \\
\hline T9 & $(-)$ & 3.23 & 480.225 & 479.2173 & Gln Phe Trp & $\mathrm{C} 25 \mathrm{H} 29 \mathrm{~N} 5 \mathrm{O} 5$ \\
\hline
\end{tabular}


TABLE 4: Continued.

\begin{tabular}{|c|c|c|c|c|c|c|}
\hline Sample & Ganoderma & $\mathrm{RT}$ & $m / z$ & Mass & Name & Molecular formula \\
\hline T9 & $(-)$ & 3.5 & 601.155 & 578.1652 & Rhoifolin & C27 H30 O14 \\
\hline T9 & $(-)$ & 5.2 & 395.174 & 377.1404 & Ofloxacin-N-oxide & C18 H20 F N3 O5 \\
\hline T9 & $(-)$ & 5.26 & 395.206 & 377.1723 & Gln Lys Cys & C14 H27 N5 O5 S \\
\hline T9 & $(-)$ & 5.69 & 205.062 & 182.0728 & 9-Hydroxyfluorene & $\mathrm{C} 13 \mathrm{H} 10 \mathrm{O}$ \\
\hline T9 & $(-)$ & 12.06 & 274.275 & 273.2672 & C16 sphinganine & C16 H35 N O2 \\
\hline T9 & $(-)$ & 12.19 & 318.3 & 317.2924 & Phytosphingosine & C18 H39 N O3 \\
\hline T9 & $(-)$ & 12.49 & 409.13 & 408.1232 & Ichthynone & C23 H20 O7 \\
\hline T9 & $(-)$ & 16.17 & 599.411 & 598.4032 & Mytiloxanthin & C40 H54 O4 \\
\hline T9 & $(-)$ & 20.08 & 797.52 & 774.5304 & $\begin{array}{l}\text { 1,2 di-(9Z,12Z,15Z-octadecatrienoyl)-3- } \\
\text { O-beta-D-galactosyl-sn-glycerol }\end{array}$ & C45 H74 O10 \\
\hline T9 & $(-)$ & 21.5 & 585.433 & 584.425 & Myxol & C40 H56 O3 \\
\hline T9 & $(-)$ & 21.5 & 601.427 & 600.4195 & Capsanthin 3,6-epoxide & C40 H56 O4 \\
\hline T9 & $(-)$ & 21.69 & 646.254 & 645.2443 & Acarbose (Glucobay) & C25 H43 N O18 \\
\hline T9 & $(-)$ & 21.49 & 607.29 & 568.3266 & $\begin{array}{c}\text { (3a,5b,7a)-23-carboxy-7-hydroxy-24- } \\
\text { norcholan-3-yl, } \\
\text { b-D-glucopyranosiduronic acid }\end{array}$ & C30 H48 O10 \\
\hline $\mathrm{T} 10$ & $(-)$ & 0.97 & 293.065 & 254.1022 & Dyphylline & C10 H14 N4 O4 \\
\hline $\mathrm{T} 10$ & $(-)$ & 1.03 & 265.025 & 226.0623 & Anthralin & C14 H10 O3 \\
\hline $\mathrm{T} 10$ & $(-)$ & 1.17 & 287.112 & 264.1228 & 1-(5-Ketohexyl)-3-methylxanthine & C12 H16 N4 O3 \\
\hline $\mathrm{T} 10$ & $(-)$ & 2 & 362.243 & 344.2091 & Oxyphencyclimine & $\mathrm{C} 20 \mathrm{H} 28 \mathrm{~N} 2 \mathrm{O} 3$ \\
\hline $\mathrm{T} 10$ & $(-)$ & 2.29 & 411.2 & 410.1925 & Flumethasone & $\mathrm{C} 22 \mathrm{H} 28 \mathrm{~F} 2 \mathrm{O} 5$ \\
\hline $\mathrm{T} 10$ & $(-)$ & 2.29 & 409.185 & 408.1781 & Trp Phe Gly & $\mathrm{C} 22 \mathrm{H} 24 \mathrm{~N} 4 \mathrm{O} 4$ \\
\hline $\mathrm{T} 10$ & $(-)$ & 2.45 & 621.218 & 620.2108 & Diethylstilbestrol diglucuronide & C30 H36 O14 \\
\hline $\mathrm{T} 10$ & $(-)$ & 2.92 & 480.225 & 479.2179 & Gln Phe Trp & C25 H29 N5 O5 \\
\hline $\mathrm{T} 10$ & $(-)$ & 3.25 & 480.225 & 479.2187 & Gln Phe Trp & C25 H29 N5 O5 \\
\hline $\mathrm{T} 10$ & $(-)$ & 3.64 & 264.159 & 246.1251 & Santonin & C15 H18 O3 \\
\hline $\mathrm{T} 10$ & $(-)$ & 5.23 & 395.207 & 377.1738 & Gln Cys Lys & C14 H27 N5 O5 S \\
\hline $\mathrm{T} 10$ & $(-)$ & 12.19 & 318.302 & 317.2943 & Phytosphingosine & C18 H39 N O3 \\
\hline $\mathrm{T} 10$ & $(-)$ & 12.72 & 288.291 & 287.2833 & C17 sphinganine & C17 H37 N O2 \\
\hline $\mathrm{T} 10$ & $(-)$ & 13.14 & 288.29 & 287.2824 & C17 sphinganine & C17 H37 N O2 \\
\hline $\mathrm{T} 10$ & $(-)$ & 14.93 & 316.321 & 298.2873 & 11-Methyl-octadecanoic acid & $\mathrm{C} 19 \mathrm{H} 38 \mathrm{O} 2$ \\
\hline $\mathrm{T} 10$ & $(-)$ & 14.97 & 272.295 & 254.2608 & 14-Methyl-8-hexadecen-1-ol & $\mathrm{C} 17 \mathrm{H} 34 \mathrm{O}$ \\
\hline $\mathrm{T} 10$ & $(-)$ & 15.51 & 304.286 & 286.2515 & 17-Hydroxy-heptadecanoic acid & C17 H34 O3 \\
\hline $\mathrm{T} 10$ & $(-)$ & 16.17 & 599.409 & 598.4011 & Mytiloxanthin & C40 H54 O4 \\
\hline $\mathrm{T} 10$ & $(-)$ & 17.76 & 248.197 & 230.1627 & Leu Val & $\mathrm{C} 11 \mathrm{H} 22 \mathrm{~N} 2 \mathrm{O} 3$ \\
\hline $\mathrm{T} 10$ & $(-)$ & 21.31 & 597.238 & 574.2481 & p-hydroxy atorvastatin & C33 H35 F N2 O6 \\
\hline T10 & $(-)$ & 21.48 & 585.433 & 584.4252 & Myxol & $\mathrm{C} 40 \mathrm{H} 56 \mathrm{O} 3$ \\
\hline $\mathrm{T} 10$ & $(-)$ & 21.63 & 607.287 & 568.3253 & $\begin{array}{c}\text { (3a,5b,7a)-23-carboxy-7-hydroxy-24- } \\
\text { norcholan-3-yl, } \\
\text { b-D-Glucopyranosiduronic acid }\end{array}$ & C30 H48 O10 \\
\hline $\mathrm{T} 10$ & $(-)$ & 21.69 & 469.368 & 468.36 & $\begin{array}{l}1 \alpha, 25 \text {-Dihydroxy-26,27-dimethyl-22,22,23,23- } \\
\text { tetradehydro-24a,24b-dihomovitamin D3 }\end{array}$ & C31 H48 O3 \\
\hline $\mathrm{T} 10$ & $(-)$ & 21.76 & 469.368 & 468.357 & $\begin{array}{l}1 \alpha, 25 \text {-Dihydroxy-26,27-dimethyl-22,22,23,23 } \\
\text {-tetradehydro-24a,24b-dihomovitamin D3 }\end{array}$ & C31 H48 O3 \\
\hline $\mathrm{T} 10$ & $(-)$ & 21.77 & 429.375 & 428.367 & $\begin{array}{l}\text { 25-hydroxy-26,27-dimethylvitamin D3/ } \\
\text { 25-hydroxy-26,27-dimethylcholecalciferol }\end{array}$ & C29 H48 O2 \\
\hline $\mathrm{T} 10$ & $(-)$ & 22.48 & 607.287 & 606.277 & Trandolapril glucuronide & C30 H42 N2 O11 \\
\hline $\mathrm{T} 10$ & $(+)$ & 1.04 & 265.027 & 226.064 & Anthralin & C14 H10 O3 \\
\hline $\mathrm{T} 10$ & $(+)$ & 1.07 & 300.148 & 299.141 & Metoclopramide & $\mathrm{C} 14 \mathrm{H} 22 \mathrm{Cl} \mathrm{N} 3 \mathrm{O} 2$ \\
\hline
\end{tabular}


TABle 4: Continued.

\begin{tabular}{|c|c|c|c|c|c|c|}
\hline Sample & Ganoderma & RT & $m / z$ & Mass & Name & Molecular formula \\
\hline T10 & $(+)$ & 1.17 & 300.147 & 299.14 & Metoclopramide & $\mathrm{C} 14 \mathrm{H} 22 \mathrm{Cl} \mathrm{N} 3 \mathrm{O} 2$ \\
\hline $\mathrm{T} 10$ & $(+)$ & 1.98 & 362.245 & 344.211 & Oxyphencyclimine & C20 H28 N2 O3 \\
\hline $\mathrm{T} 10$ & $(+)$ & 2.27 & 409.187 & 408.18 & Trp Phe Gly & C22 H24 N4 O4 \\
\hline $\mathrm{T} 10$ & $(+)$ & 5.22 & 395.208 & 377.175 & Gln Cys Lys & $\mathrm{C} 14 \mathrm{H} 27 \mathrm{~N} 5 \mathrm{O} 5 \mathrm{~S}$ \\
\hline $\mathrm{T} 10$ & $(+)$ & 11.98 & 274.254 & 273.246 & 10Z,13Z,16Z-nonadecatrienenitrile & C19 H31 N \\
\hline $\mathrm{T} 10$ & $(+)$ & 12.15 & 230.248 & 212.214 & Myristaldehyde & $\mathrm{C} 14 \mathrm{H} 28 \mathrm{O}$ \\
\hline $\mathrm{T} 10$ & $(+)$ & 12.17 & 318.3 & 317.293 & Phytosphingosine & $\mathrm{C} 18 \mathrm{H} 39 \mathrm{~N} \mathrm{O} 3$ \\
\hline $\mathrm{T} 10$ & $(+)$ & 17.76 & 243.139 & 242.131 & 6E,8E,14E-Hexadecatriene-10,12-diynoic acid & C16 H18 O2 \\
\hline $\mathrm{T} 10$ & $(+)$ & 17.87 & 243.138 & 242.131 & 6E,8E,14E-Hexadecatriene-10,12-diynoic acid & $\mathrm{C} 16 \mathrm{H} 18 \mathrm{O} 2$ \\
\hline $\mathrm{T} 10$ & $(+)$ & 18.22 & 419.281 & 418.273 & Simvastatin & C25 H38 O5 \\
\hline $\mathrm{T} 10$ & $(+)$ & 21.29 & 645.275 & 606.312 & $\begin{array}{l}\text { 1,25-Dihydroxy-20S-21-(3-hydroxy-3- } \\
\text { methylbutyl) } \\
\text {-23-yne-26,27-hexafluorovitamin D3 }\end{array}$ & C32 H44 F6 O4 \\
\hline $\mathrm{T} 10$ & $(+)$ & 21.7 & 646.258 & 645.249 & Acarbose (Glucobay) & C25 H43 N O18 \\
\hline
\end{tabular}



FIGURE 5: Heatmap of 190 metabolite compounds in 10 types of NPK treatment oil palm seedling. A color matrix represents the mean values of the metabolite compounds in two biological replicates of oil palm. Characterization of the underlying metabolites is presented in Table 4. 


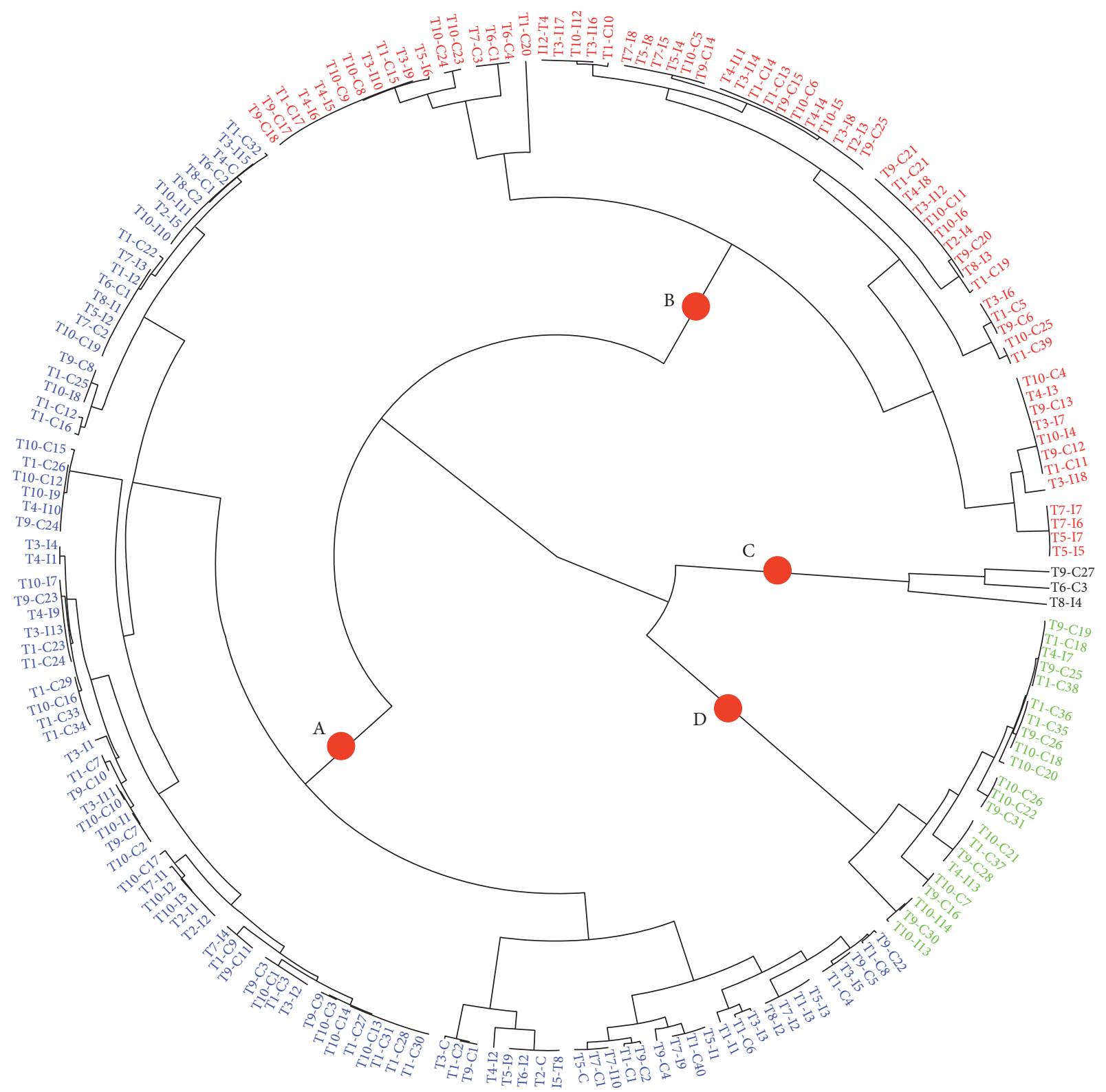

Figure 6: Fan plot showing all metabolite compounds of oil palm in both forms of control $(-\mathrm{G})$ and inoculated with Ganoderma (+G), under different NPK treatments. Four different groups A, B, C, and D represent the $\mathrm{m} / z$ mean values of the metabolite compounds including flavonoids, phenylpropanoids, acyclic diterpenoids, and fatty acid derivative.

and the plant can no longer benefit from these mechanisms [25].

It was reported that after a plant was challenged by potentially pathogenic microorganisms, the plant will respond by effecting changes in the composition and physical properties of its cell walls [26]. Firstly, they can degrade the cell wall of the pathogen or disrupt its deposition, eventually contributing to the pathogen death. Secondly, they can release cell wall fragments that act as elicitors of active host defense response. In addition, the plant will produce secondary metabolites that serve to isolate and limit the spread of the invading pathogen and also limit necrotic lesions at the site of the invasion. These responses are collectively known as hypersensitive reaction. Following infection, PR proteins accumulate in leaves and other organs, where they may comprise more than $10 \%$ of the total soluble protein. It was reported that there is a close relationship between glucanase and chitinase activity because it has been proposed that glucanase and chitinase would act synergistically together to affect or inhibit fungal growth either by lysis of the hyphal tips [26] or by interfering with the correct balance between fungal cell wall synthesis and wall hydrolysis during cell wall extension of the hyphal tip [27, 28].

Although the level of PR proteins increased in the $G$. boninense infected seedlings for the trial duration period, it appears that they are not sufficient or reach effective levels too late to stop the fungal from growth. This was supported by Van Loon who reported that defense mechanisms are often activated late in the infection process when the pathogen 


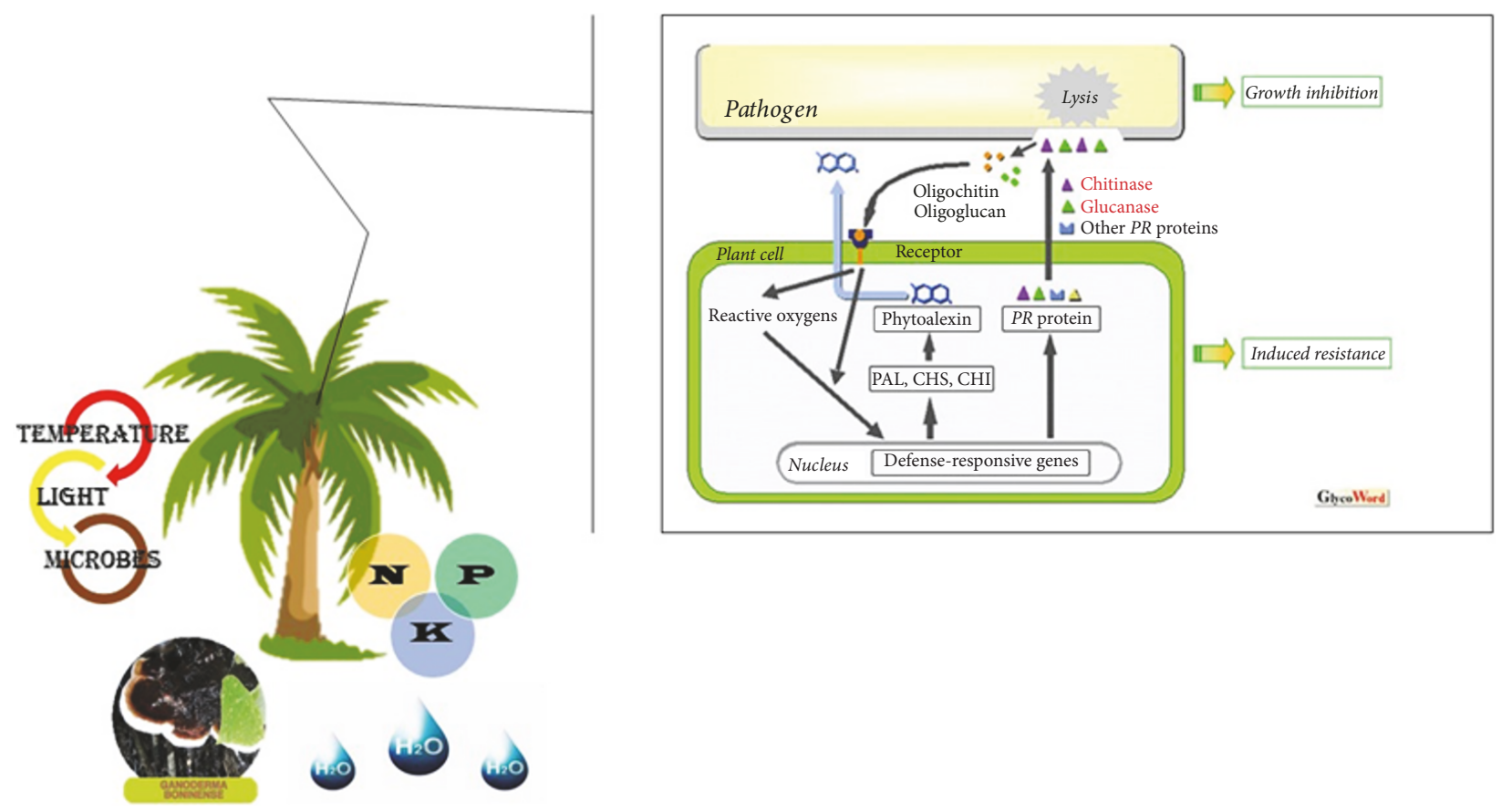

FIGURE 7: Schematic model of oil palm, Ganoderma boninense, fertilizer regime interaction focusing on the role of plant lytic enzymes (Glycoforum: http://www.glycoforum.gr.jp). This schematic model indicates the contribution of PR proteins in response to macronutrients nutrition in oil palm with Ganoderma infection. Plants produce $\beta$-1,3-glucanases, chitinase, POX, and PAL during the process of pathogenesis for self- defense, and pathogens struggle against them. Application of NPK nutrients, especially K fertilizing, might either act as elicitors triggering the production of glucanase, chitinase, POX, and PAL activities or be involved in secondary metabolite profiling associated with induced resistance.

had colonized the tissue and the plant can no longer benefit from these mechanisms [25]. Low level of chitinase activity may also be the factor of high susceptibility among oil palm seedlings to $G$. boninense infection. Other than that, low level of chitinase activity may lower the hydrolysis effect of glucanase activity since both enzymes work synergistically [26]. With the rapid advancement in genetic transformation, oil palm seedlings resistance to Ganoderma infection might be improved by regulation of chitinase gene expression and other genes controlling host resistance [29]. As mention earlier, PAL catalyzes the first committed step in phenylpropanoid metabolism which is vital for the synthesis of phenolic compounds including lignin [30]. Most evidence suggests that PAL activity is correlated not only with lignin biosynthesis, but also with the production of salicylic acid precursors. Salicylic acid is reported to play a central role in genetically determined plant disease resistance [31]. Apart from that, the POX activity is not always associated with lignification [32]. The POXs are mainly involved in hydrogen peroxide $\left(\mathrm{H}_{2} \mathrm{O}_{2}\right)$ scavenging to alleviate oxidative stress caused by reactive oxygen species [20], thereby playing a detoxifying role. Since they are also implicated in tissue growth and differentiation in plants, expression of peroxidases in roots might indicate simple root differentiation activity and not necessarily lignin biosynthesis [33].

As has been known, POXs are key enzymes in the cell wall-building process, and it has been suggested that extracellular or wall-bound peroxidases would enhance plant resistance by the construction of a cell wall barrier that may impede pathogen ingression and spread [34]. Peroxidases are also involved in HR and for the polymerization of cell wall components such as lignin, suberin, and extensin, leading to the formation of barriers for infecting pathogens [35]. Even though many peroxidases are found in most plant species and are expressed constitutively, some isozymes appear to be inducible upon pathogen infection.

The application of $\mathrm{N}, \mathrm{P}$, and $\mathrm{K}$ nutrients as observed here may play important role in directly stimulating the inducible compounds in oil palm seedlings. Although this study has also shown that macronutrient application has not stopped the progress of $G$. boninense, the infection was delayed. The occurrence of induced resistance subsequently implied enhanced tolerance of oil palm seedlings towards development of $G$. boninense and delayed the onset of symptoms. Effect of different nutrients doses was obviously observed among results of secondary metabolite compounds. For instance, only a few but important number of metabolite compounds observed in sample T6 leads to the highest activities of four antioxidant enzymes activities. That shows the significant importance of $\mathrm{K}$ fertilizing for oil palm trees among other fertilizers. Although highest $\mathrm{N}$ fertilizing of sample T2 led plants to produce different metabolite compounds and consequently caused the highest activities of glucanase activities, it failed for chitinase activities among other treatments, which is most probably due to lack of enough K. Sample T8 with optimum levels of NPK fertilizing 
and extracted different metabolite compounds showed the highest activities for all antioxidant enzyme activities among other treatments. Samples T1, T3, T4, T5, T7, and T9 that were treated with different levels of fertilizing, produced variety of metabolite compounds mostly in control type $(-G)$, which were not effective enough for plants after inoculation with Ganoderma. Extracted metabolite compound as well as results of antioxidant enzyme activities of samples T10 with basic fertilizer (BF) and T8 with optimum level of fertilizers also confirmed the importance of using balanced NPK for oil palm trees. It is difficult to determine exact suppression mechanism with the application of macronutrients since other complex interactions in the soil-plant-pathogens exist. Moreover, G. boninense is notoriously adaptable, and many plant and nutrient factors may interact to contribute to different susceptibility to the oil palm seedlings. On the other hand, role of most metabolite compounds presented in oil palm seedlings under different N, P, and K treatments against Ganoderma attack has not been clear yet, though many of them have been identified in other plants as useful medicinal compounds for human health. Identifying and categorizing these compounds and their effective relation in oil palm seedlings against Ganoderma attack may be used as new markers for the early detection of disease. At the next step, besides explaining the role of micronutrients in antioxidant enzymes activities, identifying the role of extracted secondary metabolite compounds may help to formulate improved fertilizers for oil palm trees. It was revealed that susceptibility may be associated with cell maintenance and development, genes involved in the biosynthesis of lignin and phenolics and genes implicated in oxidative burst, programmed cell death, or hypersensitive responses [36].

The G. boninense disturbs the lignin and other structural components of the cell wall during infection using its enzyme activities [37, 38]. Lignin protects both cellulose and hemicellulose components from fungus enzymatic activities through chemical bonds. Ganoderma attacks the oil palm, and due to the lack of sufficient lignin, the permeability of cell wall increased. Lignin plays an important role in protecting plants from microbial degradation and decay. Also, it limits the plant's biomass conversion to biofuels. Besides all the positive effects of lignin in plant cell wall like protection of plant against several stress conditions, for the purpose of some investigation, existence of lignin will be undesirable trait. Lignin has an important role in plant defense against pathogen invasion. Lignification is a mechanism for resistance in plants. After pathogen invades the plant, lignin or lignin-like phenolic compound accumulation was shown to occur in a variety of plant-microbe interactions during the plant defense responses. Endogenous enzymes chitinase, $\beta$ 1,3-glucanases, and lignin content in plant leaves can be used as biochemical markers for identifying plant varieties resistant to fungal infection or other biotic and abiotic factors. Also by transferring pathogenesis-related (PR) proteins, such as chitinases, $\beta$-1,3-glucanases genes can induce resistance in plants to various pathogens.

During the degradation of cell wall in oil palm, an array of cell wall degrading enzymes are expected to be released by Ganoderma to ensure successful colonization and degradation of the intact root tissues. The defense mechanism fails if a virulent pathogen, such as $G$. boninense, avoids triggering, suppresses resistance reaction, or evades the effects of activated defense in oil palm seedlings. Consequently, the infection becomes apparent. Researchers indicated that a disease can be reduced when defense mechanisms are triggered by a stimulus prior to infection by a plant pathogen $[25,39]$. Hence, lignin is an obstacle point to protect the inner cell wall against fungus infections [40]. It has been reported that decreasing the susceptibility of plants against fungus has been achieved by increasing lignin in plant cell wall [41]. Therefore, it seems that using these mechanisms may increase G. boninense tolerance in oil palm. Lignocelluloses refer to plant cell in which lignin is associated closely with cellulose and hemicelluloses of cell wall. Lignin acts as a physical barrier to pathogen attack and, in the xylem tissue of plants, provides a water impervious seal throughout cell walls. Lignin forms chemical bonds directly against enzymatic attack of pathogens and protects more amenable hemicelluloses and cellulose [42]. The polymeric lignin structure involves at least three building units in monomeric form. The term "lignin" refers to a big group of polymers involved in oxidative combinatory of 4-hydroxyphenylpropanoids [43]. Hydroxycinnamyl alcohols, sinapyl alcohol, coniferyl alcohol, and a small amount of p-coumaryl alcohol are involved in the formation of the main composition of the lignin building [40].

Mineral nutrition also affects the formation of mechanical barriers in plant tissue. As leaves age, the accumulation of silicon $(\mathrm{Si})$ in the cell walls helps form a protective physical barrier to fungal penetration $[44,45]$. Excessively high $\mathrm{N}$ levels lower the Si content and increase susceptibility to fungal diseases.

The secondary cell wall between the middle lamella and the plasma membrane is deposited with a large amount of lignin. Although the composition of lignin, pectin, hemicelluloses, and cellulose microfibril leads to the production of the impervious and rigid secondary cell wall in plants, lignin is the most effective factor on the secondary cell wall structure. However, Ganoderma needs other sources of food, such as cellulose and pectin rather than lignin, to be able to break down plant. Notwithstanding various factors to increase lignin in plant cell wall, it was reported that the most effective factors of lignin biosynthesis are abiotic and biotic stresses [46]. The Ganoderma boninense obtains its required energy for causing the disease from lignin degradation of cell wall, although Paterson reported that pectin and starch also play a light role in surviving fungi [42]. When Ganoderma attacks the plants, spore of fungi in favorable condition starts to develop its new cells, and then fungi cells become hyphae that later create mycelium. Mycelium of fungi forms a lump which grows out of the soil when mycelium penetrates into the oil palm cells; it uses the lignin of the cell wall and continues to destruct the plant. When G. boninense attacks the oil palm, it tries to reach the lignin components of the cell wall; this period of time in different plants may vary based on cell wall thickness.

In a research on the BSR of oil palm, infection symptoms appeared on the roots of inoculated plants throughout 
5 months [47]. It was shown that penetration of fungus mycelium into the cell wall of oil palm root surface occurred in both epidermis and exodermises layers; this engagement between fungus and root surface can be limited to the primary contact point or cover root completely [37]. It can be understood that the main and the most important step in controlling Ganoderma disease is related to the cell wall thickness, particularly in the first layer. By this way, the fungi mycelium contact with the middle lamella of the plant cell wall will be limited. Thus, the BSR disease rate of oil palm will reduce. It was revealed that a Ganoderma colonization may occur along with unwounded root parts and then may develop mostly through the cortex part of the inner cell wall [37].

\section{Conclusion}

This study suggests the involvement of PR proteins in response to macronutrients nutrition in oil palm with and without Ganoderma infection. The observed trend of changes in the infected and uninfected plants was a slightly higher activity for $\beta$-1,3-glucanases, chitinase, POX, and PAL during the process of pathogenesis. The PR proteins gave positive response to the interaction between oil palm seedlings and Ganoderma infection. Although the response was activated systematically, they were short-lasting as the changes in enzymes activities appeared before the occurrence of visible symptoms. These enzymatic reactions may be useful as early markers of stress condition in oil palm to Ganoderma infection. Though direct evidence for the causal role of these enzymes was lacking, this study has proved that the accumulation of PR in oil palm seedlings infected by Ganoderma may be related to systemic acquired resistance (SAR). This is because there were some changes in the PR proteins that can be detected in the roots. This indicated that the increase in the PR proteins was a plant response to infection, not simply a contribution of the hyphal enzymes per se. On the other hand, the metabolite profiling of oil palm offers an improvement to the comprehending of the biosynthetic pathways responses to environmental changes and acts as the platform for further exploration and identification of different metabolite markers for BSR disease detection.

However, whether or not the N, P, and K macronutrients application resulted in PR proteins induction, which plays a direct role in the disease resistance, remains unclear and needs to be further investigated. Application of NPK nutrients, especially $\mathrm{K}$ fertilizing, might either act as elicitor triggering the production of glucanase, chitinase, POX, and PAL activities or be involved in secondary metabolite profiling associated with induced resistance. Many plant enzymes are involved in defenses reactions against plant pathogens. The results of this study could be useful for developing new strategies with proper nutrition, which may decrease Ganoderma diffusion and its growth rate in peat soil.

\section{Conflicts of Interest}

The authors declare that they have no conflicts of interest.

\section{Acknowledgments}

The senior author (Mahbod Sahebi) would like to express sincere gratitude to Universiti Putra Malaysia (UPM) for the financial support and research facilities.

\section{References}

[1] F. Y. Ng, F. K. Yew, Y. Basiron, and K. Sundram, "A renewable future driven with Malaysian palm oil-based green technology. Journal of Oil Palm," Environment and Health, vol. 2, p. 1, 2012.

[2] E. S. Bakar, J. Hao, Z. Ashaari, and A. Choo Cheng Yong, "Durability of phenolic-resin-treated oil palm wood against subterranean termites a white-rot fungus," International Biodeterioration \& Biodegradation, vol. 85, pp. 126-130, 2013.

[3] C.-L. Ho and Y.-C. Tan, "Molecular defense response of oil palm to Ganoderma infection," Phytochemistry, vol. 114, pp. 160-169, 2015.

[4] J.-W. Shin, J.-H. Pyeon, S.-M. Son, J.-Y. Jeong, and J.-Y. Park, "Performance evaluation of a field-scale pilot bioreactor for anaerobic treatment of palm oil mill effluent," International Biodeterioration \& Biodegradation, vol. 95, pp. 89-92, 2014.

[5] A. Kandan, R. Bhaskaran, and R. Samiyappan, "Ganoderma - a basal stem rot disease of coconut palm in south Asia and Asia pacific regions," Archives of Phytopathology and Plant Protection, vol. 43, no. 15, pp. 1445-1449, 2010.

[6] A. Idris, D. Swinburne, T. TR Watt, O. Dimaro, E. Nwosu, and K. SO Rajagoipalan, "The identity of Ganoderma species responsible for BSR disease of oil palm in Malaysia-morphological characteristics," MPOB Information Series, vol. No. 77a, 2000.

[7] F. Sanderson, C. Pilotti, and P. Bridge, Basidiospores: their influence on our thinking regarding control strategy for basal stem rot of oil palm Ganoderma Diseases Perennial Crops, P. Bridge, J. Flood, and M. Holderness, Eds., CABI Publishing, Wallingford, UK, 2000.

[8] M. Iriti and F. Faoro, "Chemical diversity and defence metabolism: How plants cope with pathogens and ozone pollution," International Journal of Molecular Sciences, vol. 10, no. 8, pp. 3371-3399, 2009.

[9] S. Diabate, H. D. Franqueville, B. Adon, O. A. Coulibaly, and S. Ake, "The role of phenolic compounds in the determination of wilt disease tolerance of oil palm (Elaeis guineensis JACQ)," African Journal of Biotechnology, vol. 8, no. 21, pp. 5679-5690, 2009.

[10] J. H. Grove and M. E. Sumner, "Yield and leaf composition of sunflower in relation to N, P, K, and lime treatments," Fertilizer Research, vol. 3, no. 4, pp. 367-378, 1982.

[11] I. Cakmak, C. Hengeler, and H. Marschner, "Changes in phloem export of sucrose in leaves in response to phosphorus, potassium and magnesium deficiency in bean plants," Journal of Experimental Botany, vol. 45, no. 278, pp. 1251-1257, 1994.

[12] T. M. De La Rosa, R. Julkunen-Tiitto, T. Lehto, and P. J. Aphalo, "Secondary metabolites and nutrient concentrations in silver birch seedlings under five levels of daily UV-B exposure and two relative nutrient addition rates," New Phytologist, vol. 150, no. 1, pp. 121-131, 2001.

[13] N. Stamp, "Out of the quagmire of plant defense hypotheses," The Quarterly Review of Biology, vol. 78, no. 1, pp. 23-55, 2003. 
[14] T. Mondal, J. K. Datta, and N. K. Mondal, "Chemical fertilizer in conjunction with biofertilizer and vermicompost induced changes in morpho-physiological and bio-chemical traits of mustard crop," Journal of the Saudi Society of Agricultural Sciences, vol. 16, no. 2, pp. 135-144, 2017.

[15] M. Sahebi, M. M. Hanafi, A. J. van Wijnen et al., "Profiling secondary metabolites of plant defence mechanisms and oil palm in response to Ganoderma boninense attack," International Biodeterioration \& Biodegradation, vol. 122, pp. 151-164, 2017.

[16] I. Rankine and T. Fairhurst, "Field Handbook: Oil Palm Series Nursery," Potash Phosphate Institute. Potash and Phosphate Institute of Canada (, pp. IC-Iand 4T Consultants (4T, 1999.

[17] N. Nelson, "A photometric adaptation of the Somogyi method for the determination of glucose," J. biol. Chem, vol. 153, pp. 375380, 1944.

[18] M. Somogyi, "Notes on sugar determination," J. Biol. Chem, vol. $195,1952$.

[19] C. Tonon, A. Andreu, M. E. Aued, M. Van Damme, M. Huarte, and G. R. Daleo, "Defence reactions in two potato cultivars following infection with two races of Phytophthora infestans," Potato Research, vol. 41, no. 4, pp. 319-325, 1998.

[20] J. Chmielowska, J. Deckert, and J. Diaz, "Activity of peroxidases and phenylalanine ammonia-lyase in lupine and soybean seedlings treated with copper and an ethylene inhibitor," Biol Lett, vol. 45, pp. 59-67, 2008.

[21] M.-M. Chang, L. A. Hadwiger, and D. Horovitz, "Molecular characterization of a pea $\beta$-1,3-glucanase induced by Fusarium solani and chitosan challenge," Plant Molecular Biology, vol. 20, no. 4, pp. 609-618, 1992.

[22] H. Kaku, N. Shibuya, P. Xu, A. P. Aryan, and G. B. Fincher, "Nacetylchitooligosaccharides elicit expression of a single $(1 \rightarrow 3)$ $\beta$-glucanase gene in suspension-cultured cells from barley (Hordeum vulgare)," Physiologia Plantarum, vol. 100, no. 1, pp. 111-118, 1997.

[23] C. R. Voisey and A. J. Slusarenko, "Chitinase mRNA and enzyme activity in Phaseolus vulgaris (L.) increase more rapidly in response to avirulent than to virulent cells of Pseudomonas syringae pv. phaseolicola," Physiological and Molecular Plant Pathology, vol. 35, no. 5, pp. 403-412, 1989.

[24] M. S. Brzezinska, U. Jankiewicz, and M. Walczak, "Biodegradation of chitinous substances and chitinase production by the soil actinomycete Streptomyces rimosus," International Biodeterioration \& Biodegradation, vol. 84, pp. 104-110, 2013.

[25] L. C. Van Loon, "Induced resistance in plants and the role of pathogenesis-related proteins," European Journal of Plant Pathology, vol. 103, no. 9, pp. 753-765, 1997.

[26] F. Mauch, L. A. Hadwiger, and T. Boller, "Antifungal hydrolases in pea tissue: I. Purification and characterization of two chitinases and two $\beta$-1,3-glucanases differentially regulated during development and in response to fungal infection," Plant Physiology, vol. 87, no. 2, pp. 325-333, 1988.

[27] S. Bartnicki-Garcia, "Fundamental aspects of hyphal morphogenesis," in Proceedings of the in Microbe, 1973.

[28] A. Bruce, U. Srinivasan, H. J. Staines, and T. L. Highley, "Chitinase and laminarinase production in liquid culture by Trichoderma spp. and their role in biocontrol of wood decay fungi," International Biodeterioration \& Biodegradation, vol. 35, no. 4, pp. 337-353, 1995.
[29] K. K. Kumar, K. Poovannan, R. Nandakumar et al., "A high throughput functional expression assay system for a defence gene conferring transgenic resistance on rice against the sheath blight pathogen, Rhizoctonia solani," Journal of Plant Sciences, vol. 165, no. 5, pp. 969-976, 2003.

[30] T. L. W. Carver, R. J. Zeyen, M. P. Robbins, C. P. Vance, and D. A. Boyles, "Suppression of host cinnamyl alcohol dehydrogenase and phenylalanine ammonia lyase increases oat epidermal cell susceptibility to powdery mildew penetration," Physiological and Molecular Plant Pathology, vol. 44, no. 4, pp. 243-259, 1994.

[31] B. Mauch-Mani and A. J. Slusarenko, "Production of salicylic acid precursors is a major function of phenylalanine ammonialyase in the resistance of arabidopsis to Peronospora parasitica," The Plant Cell, vol. 8, no. 2, pp. 203-212, 1996.

[32] J. M. Cheeseman, "Hydrogen peroxide and plant stress: a challenging relationship," Plant Stress, vol. 1, no. 1, pp. 14-15, 2007.

[33] S. Timonen and R. Sen, "Heterogeneity of fungal and plant enzyme expression in intact Scots Pine - Suillus bovinus and - Paxillus involutus mycorrhizospheres developed in natural forest humus," New Phytologist, vol. 138, no. 2, pp. 355-366, 1998.

[34] J. Ride, "Cell walls and other structural barriers in defense," Biochemical Plant Pathology, pp. 215-236, 1983.

[35] J. B. Cooper and J. E. Varner, "Cross-linking of soluble extensin in isolated cell walls," Plant Physiology, vol. 76, no. 2, pp. 414-417, 1984.

[36] P. M. Schenk, K. Kazan, I. Wilson et al., "Coordinated plant defense responses in Arabidopsis revealed by microarray analysis," Proceedings of the National Acadamy of Sciences of the United States of America, vol. 97, no. 21, pp. 11655-11660, 2000.

[37] R. W. Rees, J. Flood, Y. Hasan, U. Potter, and R. M. Cooper, "Basal stem rot of oil palm (Elaeis guineensis); Mode of root infection and lower stem invasion by Ganoderma boninense," Plant Pathology, vol. 58, no. 5, pp. 982-989, 2009.

[38] J. Ćilerdžić, M. Stajić, and J. Vukojević, "Degradation of wheat straw and oak sawdust by Ganoderma applanatum," International Biodeterioration \& Biodegradation, vol. 114, pp. 39-44, 2016.

[39] D. K. Choudhary, A. Prakash, and B. N. Johri, "Induced systemic resistance (ISR) in plants: Mechanism of action," Indian Journal of Microbiology, vol. 47, no. 4, pp. 289-297, 2007.

[40] R. Vanholme, B. Demedts, K. Morreel, J. Ralph, and W. Boerjan, "Lignin biosynthesis and structure," Plant Physiology, vol. 153, no. 3, pp. 895-905, 2010.

[41] D. Saxena and G. Stotzky, "BT corn has a higher lignin content than non-BT corn," American Journal of Botany, vol. 88, no. 9, pp. 1704-1706, 2001.

[42] R. R. M. Paterson, "Ganoderma disease of oil palm-A white rot perspective necessary for integrated control," Crop Protection, vol. 26, no. 9, pp. 1369-1376, 2007.

[43] J. Ralph, K. Lundquist, G. Brunow et al., "Lignins: Natural polymers from oxidative coupling of 4-hydroxyphenylpropanoids," Phytochemistry Reviews, vol. 3, no. 1-2, pp. 29-60, 2004.

[44] M. Sahebi, M. M. Hanafi, A. Siti Nor Akmar et al., "Importance of silicon and mechanisms of biosilica formation in plants," BioMed Research International, vol. 2015, Article ID 396010, 16 pages, 2015. 
[45] M. Sahebi, M. M. Hanafi, M.-Y. Wong et al., "Towards immunity of oil palm against Ganoderma fungus infection," Acta Physiologiae Plantarum, vol. 37, no. 10, article no. 195, 2015.

[46] M. Tronchet, C. BalaguÉ, T. Kroj, L. Jouanin, and D. Roby, "Cinnamyl alcohol dehydrogenases-C and D, key enzymes in lignin biosynthesis, play an essential role in disease resistance in Arabidopsis," Molecular Plant Pathology, vol. 11, no. 1, pp. 83-92, 2010.

[47] R. W. Rees, J. Flood, Y. Hasan, and R. M. Cooper, "Effects of inoculum potential, shading and soil temperature on root infection of oil palm seedlings by the basal stem rot pathogen Ganoderma boninense," Plant Pathology, vol. 56, no. 5, pp. $862-$ 870, 2007. 


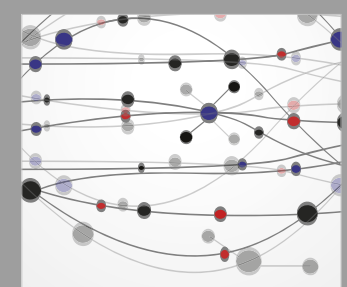

The Scientific World Journal
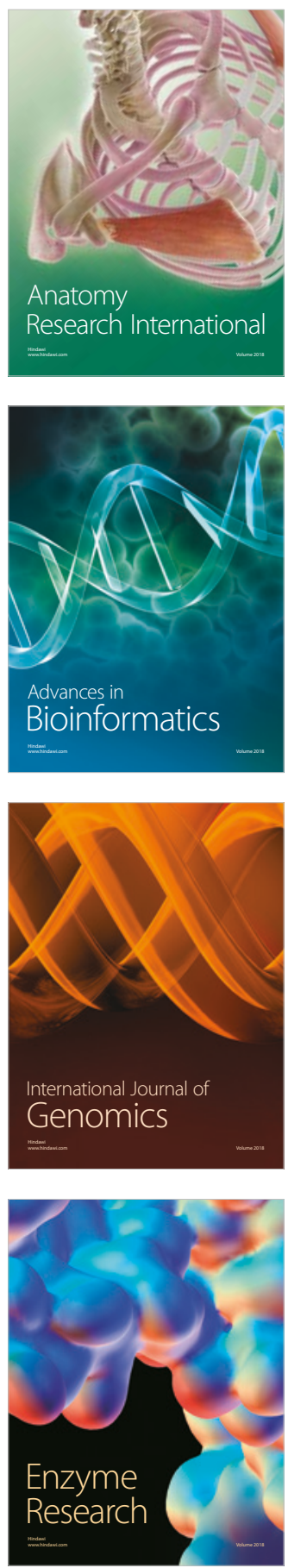
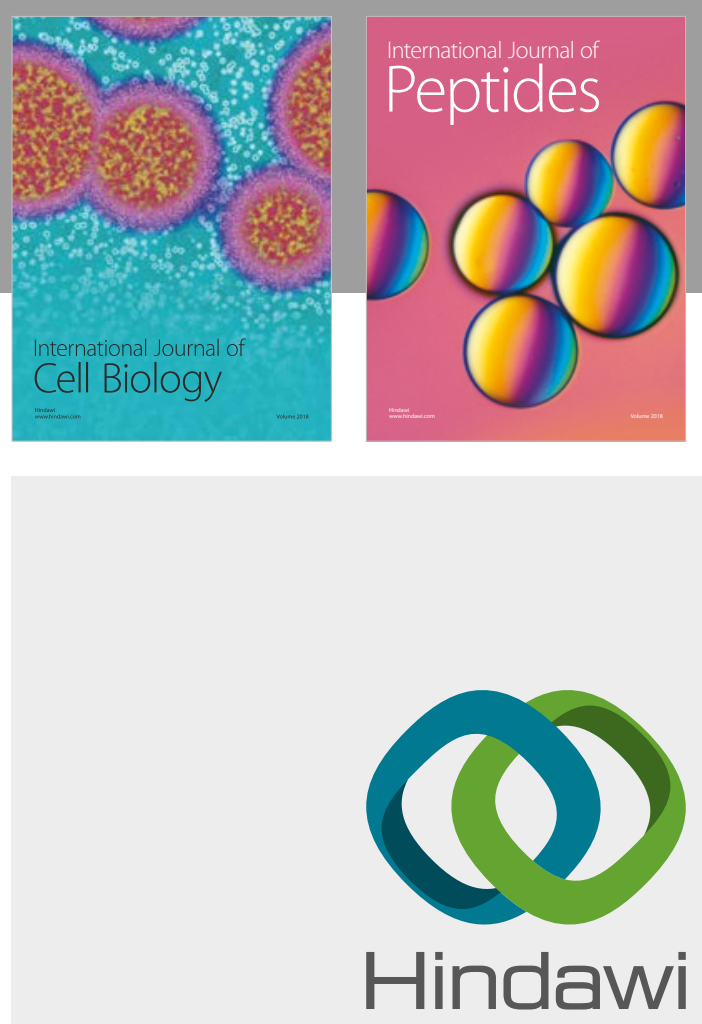

Submit your manuscripts at

www.hindawi.com
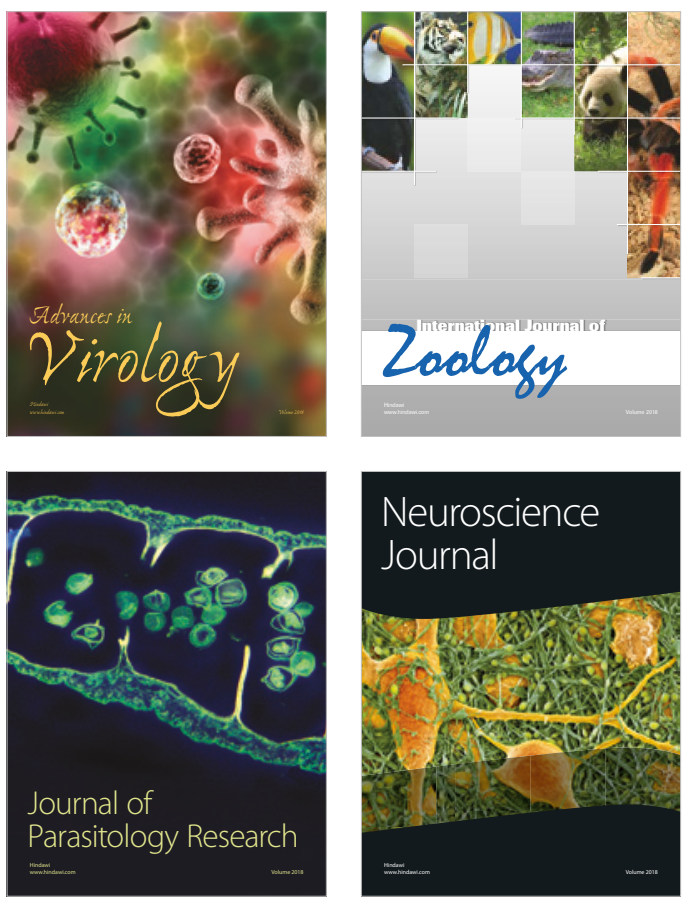
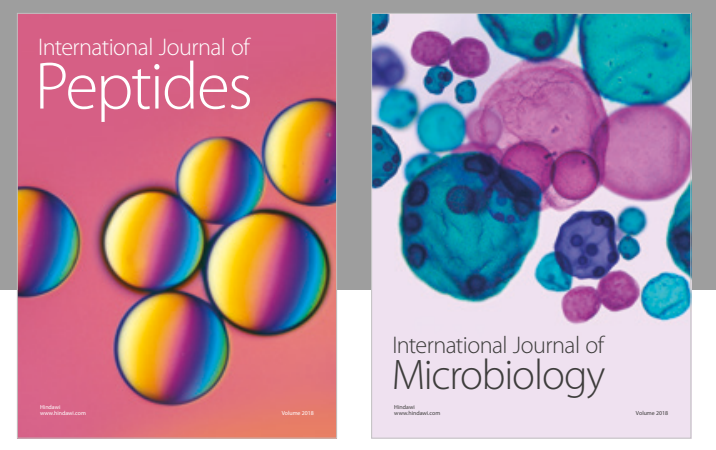

nternational Journal of Microbiology
Journal of
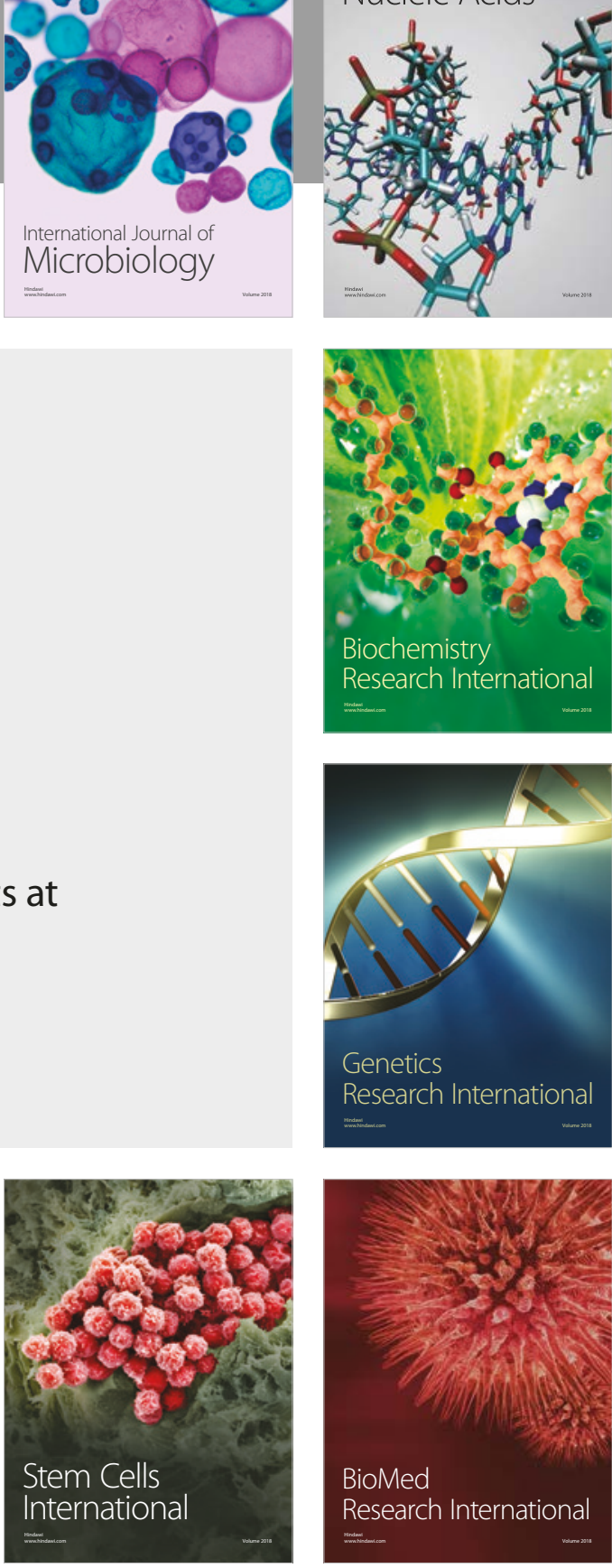
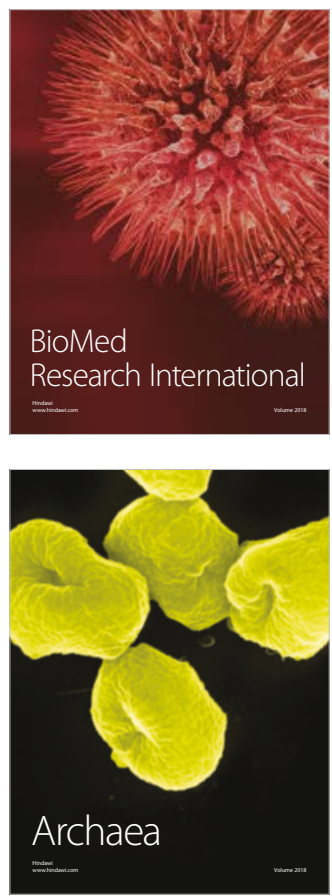